\title{
Brigantium no século XXI: aproximación aos últimos datos arqueolóxicos da ocupación galaicorromana na cidade de A Coruña (s. I-IV d.C.)
}

\author{
Brigantium at $21^{\text {th }}$ century: An approach to new archaeological data of roman ocupation \\ in the city of A Coruña $\left(1^{\text {st }} 4^{\text {th }}\right.$ centuries AD)
}

http://dx.doi.org/10.15304/galll.37.5177

\author{
Samuel Nión Álvarez \\ Universidade de Santiago de Compostela \\ samuelnionalvarez@gmail.com
}

\section{Resumo}

O seguinte artigo realiza unha revisión dos datos arqueolóxicos obtidos nos últimos 20 anos de arqueoloxía na cidade da Coruña, centrándonos no espazo que ocupou o vello asentamento de Brigantium. Se ben é certo que a ocupación romana na cidade vella coruñesa despertou o interese de múltiples investigadores durante as últimas décadas do pasado século (NAVEIRO LÓPEZ 1988; BELLO DIÉGUEZ 1991; BELLO DIÉGUEZ e VÁZQUEZ GÓMEZ 1994; PÉREZ LOSADA 2002; GONZÁLEZ GARCíA 2003, LÓPEZ PÉREZ 2004; entre outros), o certo é que neste novo milenio o interese decaeu, en paradóxica relación co aumento exponencial da información arqueolóxica dispoñible.

Nesta liña, os obxectivos principais son dous: realizar unha breve síntese que nos permita divulgar os datos arqueolóxicos máis relevantes obtidos nestas últimas dúas décadas, e actualizar o estado da cuestión sobre Brigantium; elaborando novas propostas que interpreten esta información, estudando o seu entramado "urbano" e elaborando hipóteses sobre os motivos que influíron na evolución do mesmo.

Palabras clave: Brigantium, Roma, arqueoloxía urbana, Noroeste peninsular, Gallaecia.

\begin{abstract}
Roman ocupation in the historic centre of A Coruña has been a matter of interest from the galician researchers during the last decades of the twentieth century. A demonstration of that would be the publication of several archaeological synthesis and historical aproximations with manifold points of view (NAVEIRO LÓPEZ 1988; BELLO DIÉGUEZ 1991; BELLO DIÉGUEZ e VÁZQUEZ GÓMEZ 1994; PÉREZ LOSADA 2002; GONZÁLEZ GARCÍA 2003, LÓPEZ PÉREZ 2004; among others). However, the researching has not been so sharp in the last years, concurring, paradoxically, with the hugest number of archaeological works in the history of A Coruña. Thus, this considerable amount of archaeological information were not analyzed or interpretated as a whole, neither the state of the research were been actualized.

With the aim to solve this gap on the research, a review of this twenty last years of archaeology will be proposed. This paper will not focus on the entire municipal term, but also in the place which was occupied by the old settlement of Brigantium. The main objectives are two: to draft an archaeological synthesis that allows the divulgation of this last decades of archaeological works, and to update the current state of the reasearch about Brigantium, its "urban" framework and the social processes which weighed in its development.
\end{abstract}

Keywords: Brigantium, Roma, urban archaeology, NW Iberia, Gallaecia. 


\section{INTRODUCIÓN}

A ocupación antiga da cidade da Coruña sempre despertou gran interese na comunidade académica (NAVEIRO LÓPEZ 1988; BELLO DIÉGUEZ 1991; BELLO DIÉGUEZ e VÁZQUEZ GÓMEZ, 1994; PÉREZ LOSADA 2002; GONZÁLEZ GARCÍA 2003; SAN CLAUDIO 2003; LÓPEZ PÉREZ 2004; VÁZQUEZ GÓMEZ 2008; entre outros). Durante os anos 80-90 e os primeiros 2000 publicáronse múltiples traballos de investigación dende distintas perspectivas para achegarse ao coñecemento dos primeiros momentos de ocupación da vila. Nos últimos anos este interese parece menos intenso, algo que resulta paradóxico, pois co inicio da arqueoloxía de urxencia e a ordenación das intervencións urbanas o número de intervencións arqueolóxicas realizadas aumentaron de xeito exponencial.

Dado que este "boom" na actividade arqueolóxica non trouxo consigo unha investigación arqueolóxica académica que interpretara e analizara estes datos ou un maior coñecemento divulgativo dos mesmos, resulta urxente sintetizar esta información. Nas seguintes páxinas, realizarase un compendio dos datos arqueolóxicos máis relevantes das intervencións realizadas nos últimos 20 anos. Esta data semella axeitada por varios motivos: en primeiro lugar, como dixemos, as últimas publicacións que realizaron sínteses arqueolóxicas sobre Brigantium trataron, en último lugar, intervencións realizadas no 1998 (PÉREZ LOSADA 2002: 109-140; LÓPEZ PÉREZ 2004: 48-72). Ademais, coincide co inicio da ordenación das intervencións urbanas dentro dos límites municipais da Coruña dentro do Plan Especial de Protección e Reforma Interior da Cidade Vella e Pescadería (PEPRI), co cal semella un excelente punto de partida para actualizar o estado da cuestión cos datos ofrecidos por estes vinte anos de arqueoloxía de empresa.

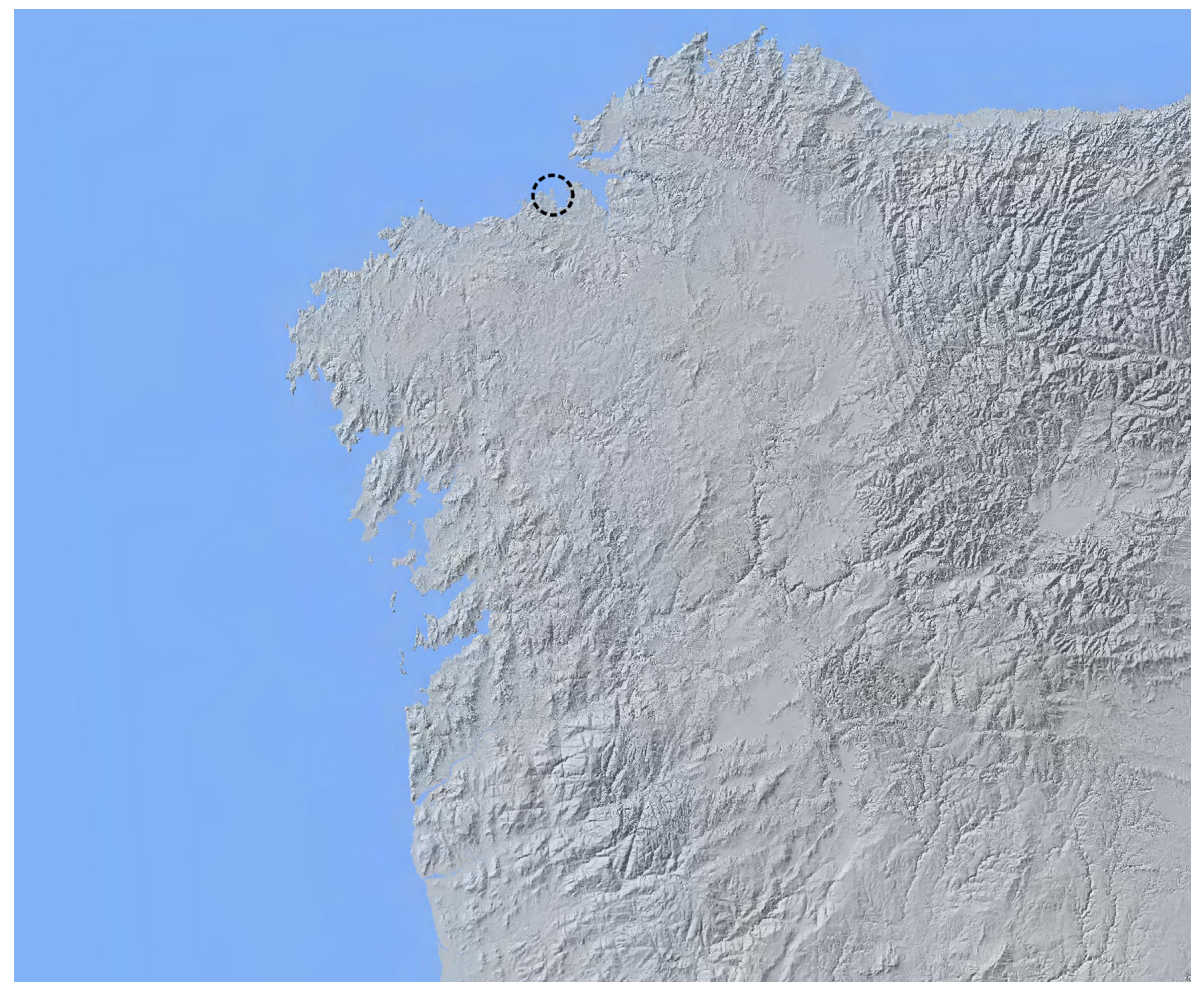

Figura 1. Localización. 
Por outra parte, esta inxente cantidade de información posibilita que se poida realizar unha actualización da vila brigantina no seu conxunto. Neste sentido, contrastar estes novos datos arqueolóxicos coas intervencións anteriores permitirá a elaboración dunha breve interpretación sobre a evolución urbana de Brigantium e as principais cuestións relacionadas cos seus procesos sociais.

\section{Metodoloxía E XESTión DA INFORMACióN}

Antes de comezar, debemos deternos brevemente para expor algunhas cuestións relacionadas coa zona de traballo, a recopilación de datos e a xestión dos mesmos. En primeiro lugar, sendo conscientes de que se realizaron intervencións con datos relevantes para estas cronoloxías dentro do termo municipal (como poden ser MÉNDEZ FERNÁNDEZ 2014, FERNÁNDEZ MALDE 2017), consideramos pertinente circunscribirnos no entorno da zona PEPRI, ao constituír esta zona un conxunto arqueolóxico que nos permite realizar unha aproximación interpretativa sobre as súas características urbanas e funcionais.

Por outra parte, debemos ser conscientes de que o conxunto total aquí exposto non abarca, nin moito menos, o total das intervencións realizadas. Neste caso, a mostraxe limítase a todas aquelas que puideron ser revisadas nas institucións pertinentes ${ }^{1}$. Resulta difícil discernir o número de intervencións arqueolóxicas realizadas, dadas as múltiples casuísticas que rodea tanto ao mundo da arqueoloxía como a cada intervención de xeito individual. Polo tanto, debemos ser conscientes de que non estamos plasmando neste artigo a totalidade da información arqueolóxica obtida, senón toda aquela á que nos foi posible acceder.

As intervencións arqueolóxicas analizadas posteriores ao 1998 son 193, das cales 118 implicaron remoción de terras (97 sondaxes e 21 escavacións en área), sendo as 75 restantes controis arqueolóxicos sen remocións de terra. Destas 193 intervencións, 73 ofreceron algún tipo de información arqueolóxica para as cronoloxías propostas. Acotando este concepto, podemos falar da existencia de 39 intervencións cun ou máis niveis de ocupación de época romana. O amplo número de intervencións estudadas imposibilita unha descrición pormenorizada de cada unha delas, polo que as que presenten unha menor cantidade de información non serán explicadas de xeito individualizado.

Aplicando este mesmo sistema cuantitativo ás intervencións anteriores a 1998, podemos apreciar un total de 23 con resultados positivos (sen contar os achados illados, moitos sen localización definida). Deles, 17 ofreceron niveis de ocupación de época antiga. Esta sinxela comparativa, que amosa a gran cantidade de información arqueolóxica recuperada nos últimos 20 anos, pon aínda máis de manifesto a necesidade de elaborar unha síntese como a aquí proposta.

1 Neste caso, o Servizo de Arqueoloxía da Dirección Xeral de Patrimonio Cultural e a Sección de Arqueoloxía da Área de Infraestruturas do Concello de A Coruña. 


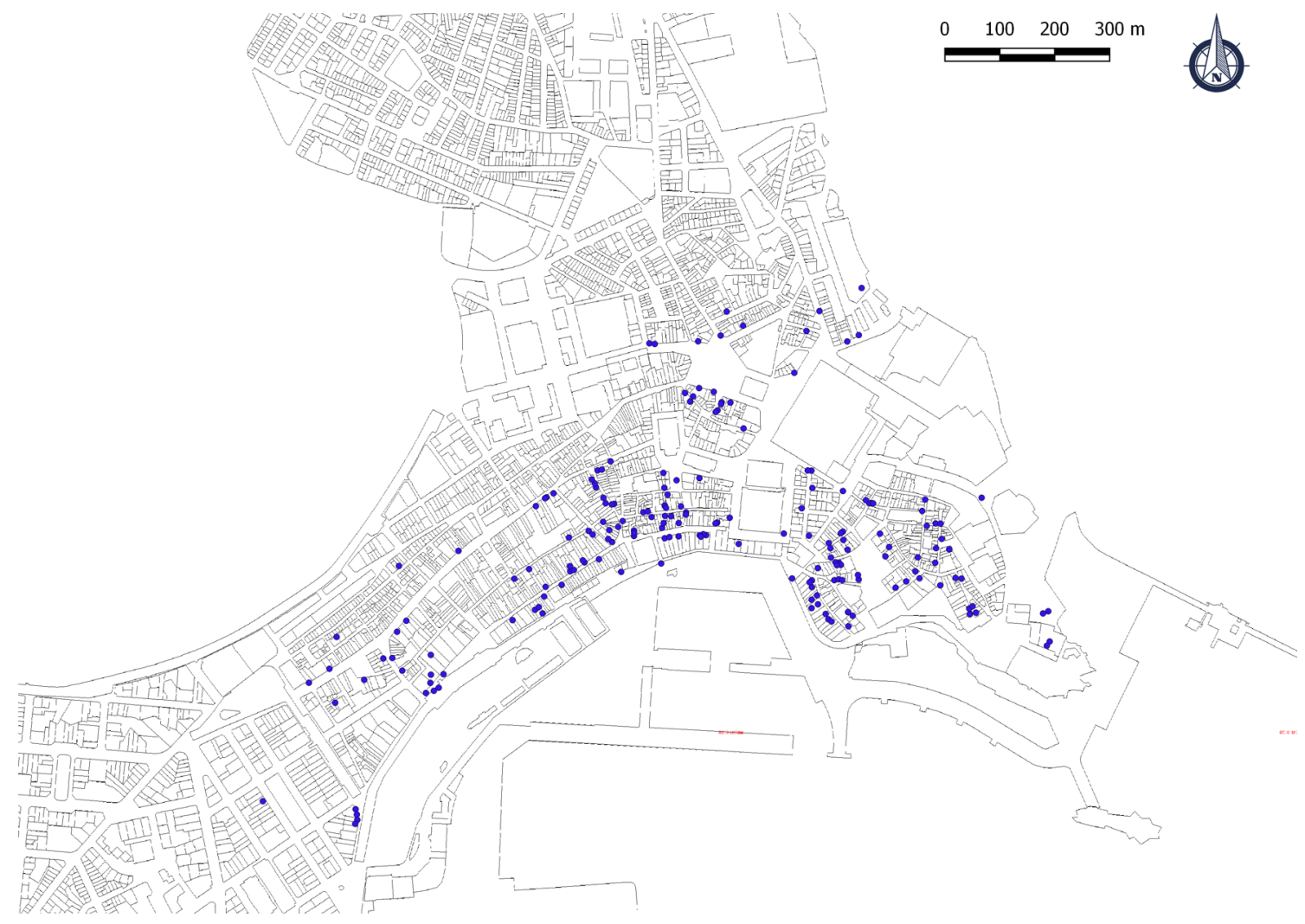

Figura 2. Mapa das intervencións arqueolóxicas realizadas a partires de 1998.

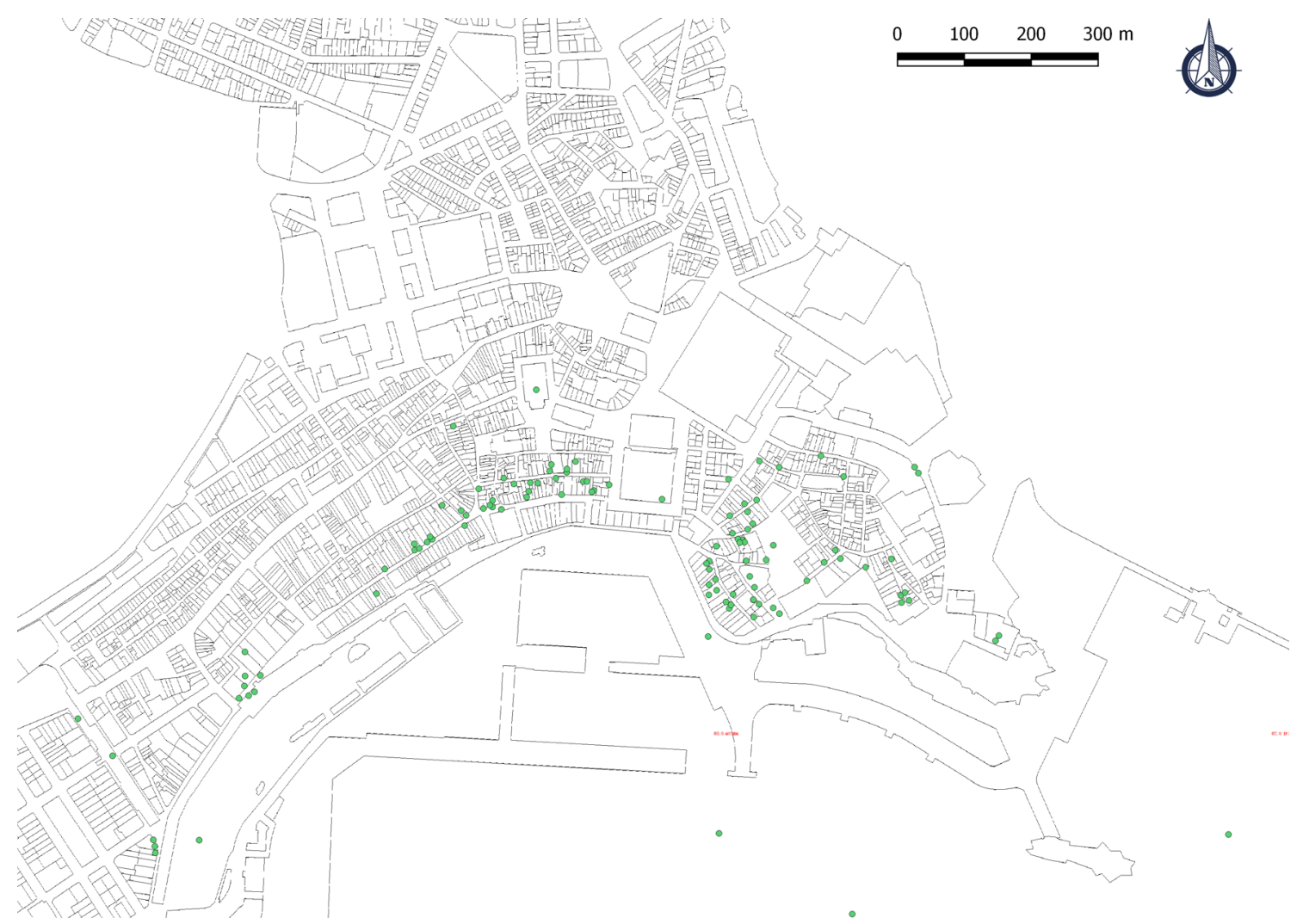

Figura 3. Emprazamentos con evidencias de ocupación romana. 


\section{Brigantium en Coruña: vinte ANOS de ARQUeoloxía}

Dado o volume de información recopilada, posiblemente sexa máis ordenado dividir o espazo en catro zonas de traballo: Cidade Vella, Pescadería e outras dúas zonas de ocupación “periférica”: Zalaeta-Orillamar e Cantóns-Orzán. Esta clasificación por sectores axudaranos tanto a ubicar os achados como a comprender a organización interna do asentamento.

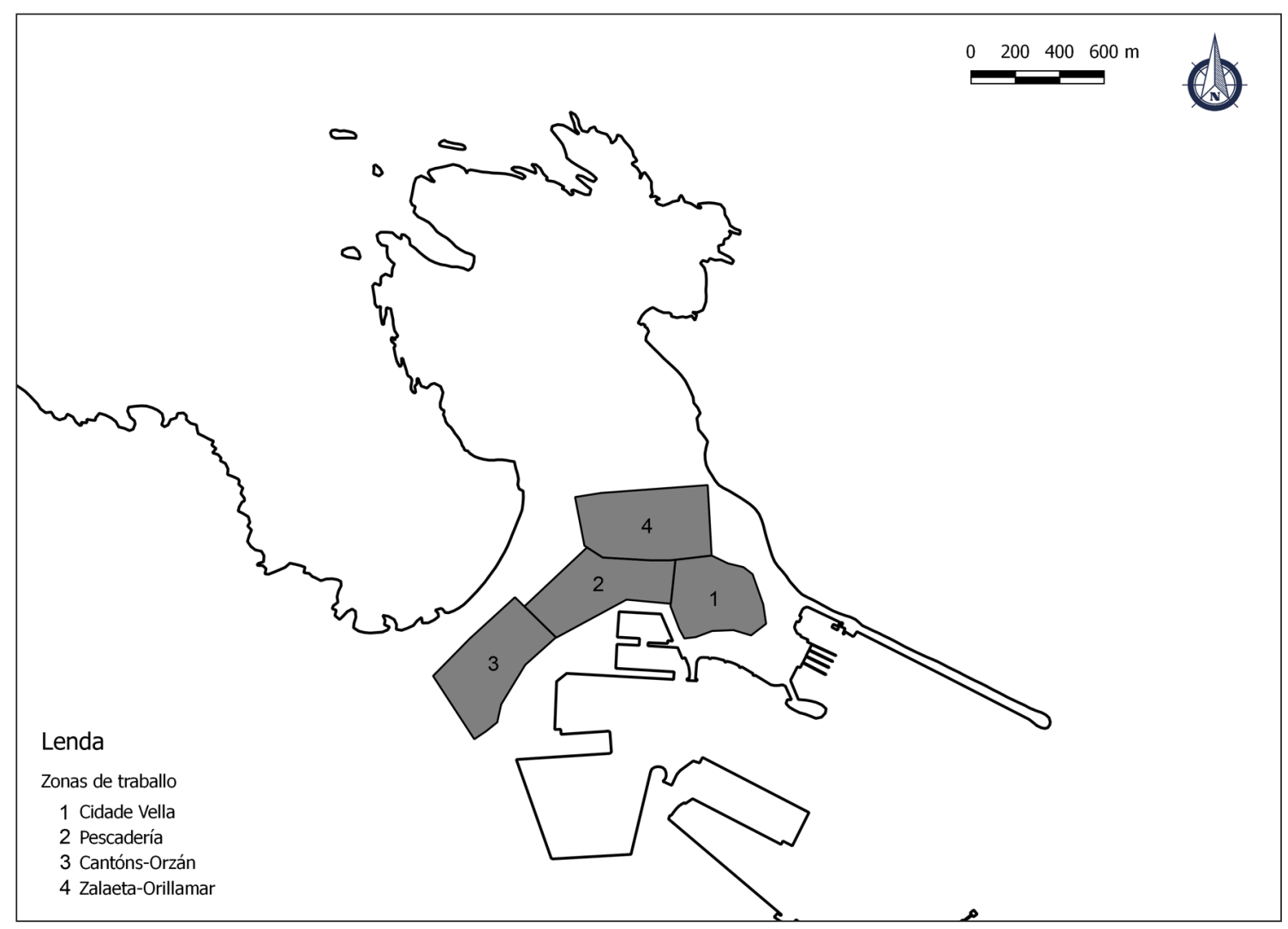

Figura 4. Zonas nas que se divide a revisión.

\section{Cidade Vella}

A zona da cidade vella abarca, grosso modo, o espazo delimitado pola rúa da Maestranza, o paseo do Parrote e a Praza de María Pita. Estamos ante a zona á que se lle presupón unha ocupación máis temperá, posiblemente asociada a funcións portuarias (BALIL ILLANA 1980: 167-173; NAVEIRO LÓPEZ 1988: 43-44; BELLO DIÉGUEZ 1991: 88-90). Este sector presenta unha escasa potencia edáfica (NAVEIRO LÓPEZ 1988: 39; TOMÁS BOTELLA 2002: 7), sendo especialmente sinalable que con notables excepcións (BELLO DIÉGUEZ \& VÁZQUEZ GÓMEZ 1994: 34; VÁZQUEZ GÓMEZ 199:, 135-138) unicamente se documentaban materiais en posición secundaria. Esta limitada potencia do solo débese en parte á situación en ladeira de gran parte da Cidade Vella, pero sobre todo á continua actividade humana que tivo lugar neste lugar durante 2000 anos (TOMÁS BOTELLA 2007b), sendo reformulada e reconstruída de forma continua. 
A pesar destas limitacións, nos últimos anos documentáronse algúns solares cunha maior potencia edáfica e arqueolóxica (situados nas rúas Damas, Tabernas ou Santo Domingo), nos que se documentaron varios niveis con cronoloxías romanas, habitualmente amortizados por recheos e construcións baixomedievais.

Esta maior potencia arqueolóxica existente nalgunhas áreas é especialmente apreciable nas intervencións arqueolóxicas realizadas por Tomás Botella nos inmobles 10 e 12 da rúa Tabernas (TOMÁS BOTELLA 2001a; 2002a; 2003a; 2003b), tamén estudados conxuntamente nunha publicación recente (LÓPEZ PÉREZ e TOMÁS BOTELLA 2010).

$\mathrm{O}^{0}{ }^{10}$, especialmente no sector orientado cara a rúa Tabernas, ofreceu nunha primeira intervención varios niveis estratigráficos romanos con estruturas asociadas (TOMÁS BOTELLA 2001a). Tras unha nova intervención que avaliaría a importancia destes restos (TOMÁS BOTELLA 2002a), documentaríase un nivel romano con catro treitos de muro perpendiculares entre si, en forma de cruz, relacionados con dous niveis de piso e pavimento superpostos. Así mesmo, no ángulo NW do solar, exhumaríase parcialmente unha estrutura pétrea complexa de forma rectangular da que resulta difícil definir a súa funcionalidade (TOMÁS BOTELLA 2002a). Resulta bastante significativa a existencia de dous niveis diacrónicos de ocupación, con presenza de múltiples reconstrucións en ambas fases de ocupación (TOMÁS BOTELLA 2002a). As diferenzas entre os niveis son notables: mentres que o primeiro nivel de ocupación consta de muros e un empedrado de boa factura, o segundo consta de construcións de menor calidade, asentando sobre o derrubo da edificación anterior. Atendendo ao conxunto material exhumado, resulta significativa a transición da terra sigillata hispánica, moi abundante no primeiro nivel, ás sigillatas tardías focenses e hispánicas do segundo (TOMÁS BOTELLA, 2002a, LÓPEZ PÉREZ e TOMÁS BOTELLA 2010). Atendendo ao estudo dos materiais, podemos datar o primeiro nivel de ocupación da estrutura en torno ao s. II d.c. (LÓPEZ PÉREZ e TOMÁS BOTELLA 2010, 177), sendo totalmente reconstruída a mediados-finais do s. III d.c., cunha fase de ocupación que podería chegar incluso ata o s. VI d.c.

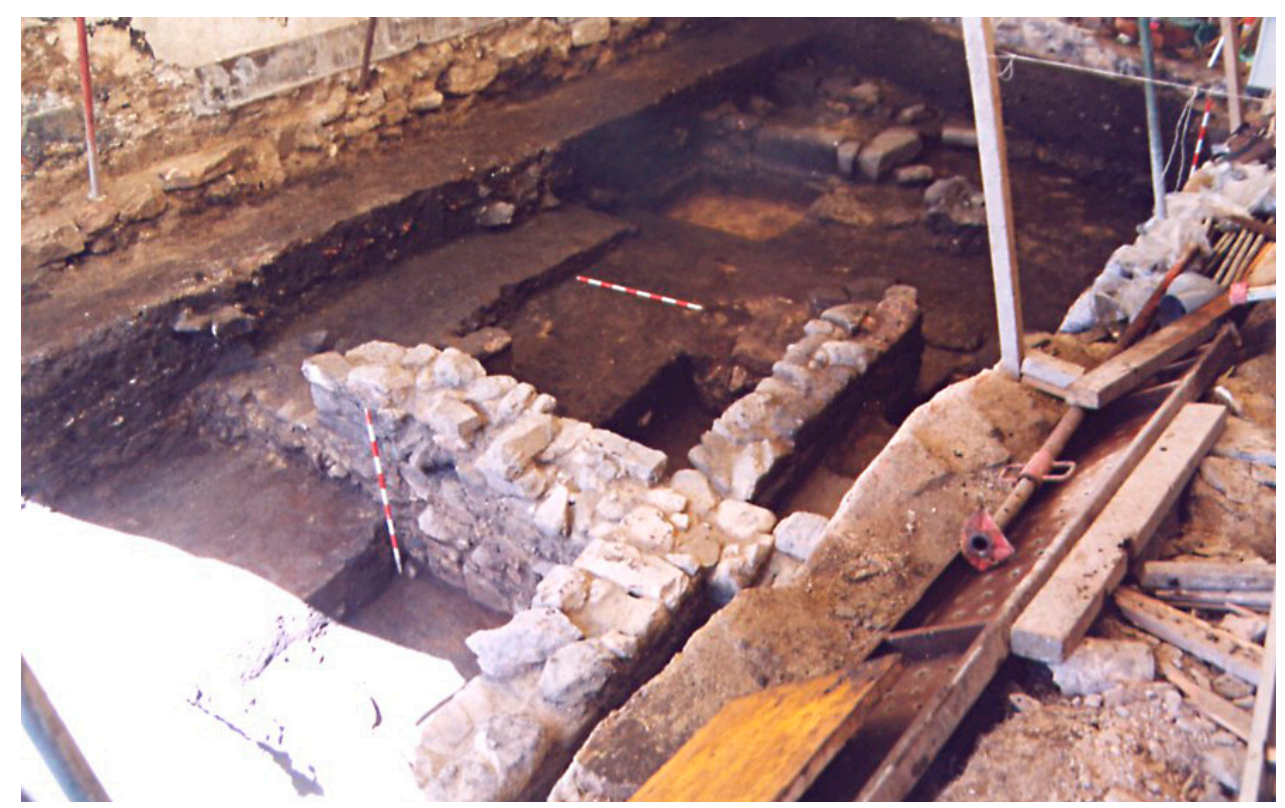

Figura 5. Detalle da escavación en Tabernas 10 (TOMÁS BOTELLA 2003a). 
Esta intervención debe de poñerse en relación coa actuación no inmoble contiguo de Tabernas 12 (TOMÁS BOTELLA 2003a; 2003b). Tras unha primeira fase de sondaxes, realízase unha escavación en área en múltiples sectores que nos documenta unha construción moi complexa e de gran superficie, con múltiples estancias diferenciadas en planta, algunhas cunha funcionalidade ben definida. O seu estado de conservación é bastante malo, e as súas cronoloxías pódense adscribir en momentos tardorromanos (s. IV-V d.C.) (TOMÁS BOTELLA 2003b). Tamén se documentou unha fase de ocupación inmediatamente anterior en peor estado de conservación, totalmente arrasada por esta construción (TOMÁS BOTELLA 2003).

Os materiais documentados poderían indicar unha posible ocupación deste espazo dende mediados do s. I d.c. (LÓPEZ PÉREZ e TOMÁS BOTELLA 2010: 179), aínda que o certo é que non se documentan materiais en contextos relacionados coa ocupación dos espazos construtivos dende o s. II d.c. Este espazo altoimperial será reformulado nalgún momento entre mediados e finais do s. III d.c., pasando a unificar esta edificación coas exhumadas en Tabernas 10 (LÓPEZ PÉREZ e TOMÁS BOTELLA 2010, 179).

Esta reformulación implicará a creación dun gran conxunto construtivo, datable dende os últimos anos do século III e con diversos detalles construtivos que nos poderían levar a considerala unha posible villa romana (LÓPEZ PÉREZ \& TOMÁS BOTELLA 2010: 180). Ademais das súas dimensións e das súas estruturas adosadas, debemos destacar o a coidada factura das súas construcións (TOMÁS BOTELLA 2003b) destacando algúns elementos construtivos como a existencia dunha base de columna no muro $\mathrm{N}$ do sector Pasadizo. Así mesmo, a entidade da súa obra queda patente ao implicar unha gran labor de acondicionamento do terreo, realizándose múltiples recheos construtivos e varias terrazas para asentar o seu edificio. Por outra parte, a súa disposición pode lembrar outros exemplos de villae ártabras como é o caso de Centroña ou Noville (LUENGO MARTÍNEZ 1962; PÉREZ LOSADA 1997). Aínda que o arqueólogo director considera a ausencia de materiais de carácter suntuario pode dificultar unha conclusión máis rotunda para este conxunto (TOMÁS BOTELLA 2003b), o certo é que este concepto de villae adoita estar moi influenciado polas villae clásicas mediterráneas (PÉREZ LOSADA 1996: 193-195; SÁNCHEZ PARDO 2008: 414). Tal e como expresan algúns autores, as villae non se tratan exclusivamente de edificacións luxosas, senón que dentro desta definición tamén poderían cadrar outro tipo de edificacións menos "ostentosas", que igualmente funcionarían como espazos de explotación produtiva que controlan unha zona máis ou menos ampla na súa contorna (SÁNCHEZ PARDO 2008: 415).

Finalmente, debemos destacar a existencia dun posible camiño (LÓPEZ PÉREZ e TOMÁS BOTELLA 2010: 179) que se dirixa cara a zona onde podería situarse o porto ou un acceso ao mesmo, evidenciando unha planificación urbanística dentro da propia cidade (LÓPEZ PÉREZ e TOMÁS BOTELLA 2010: 179-180). Este camiño sería amortizado pola unificación dos dous espazos construtivos a finais do s. III d.c., un dato que insinúa certas rupturas coa organización urbanística altoimperial, tema que abordaremos máis adiante. 


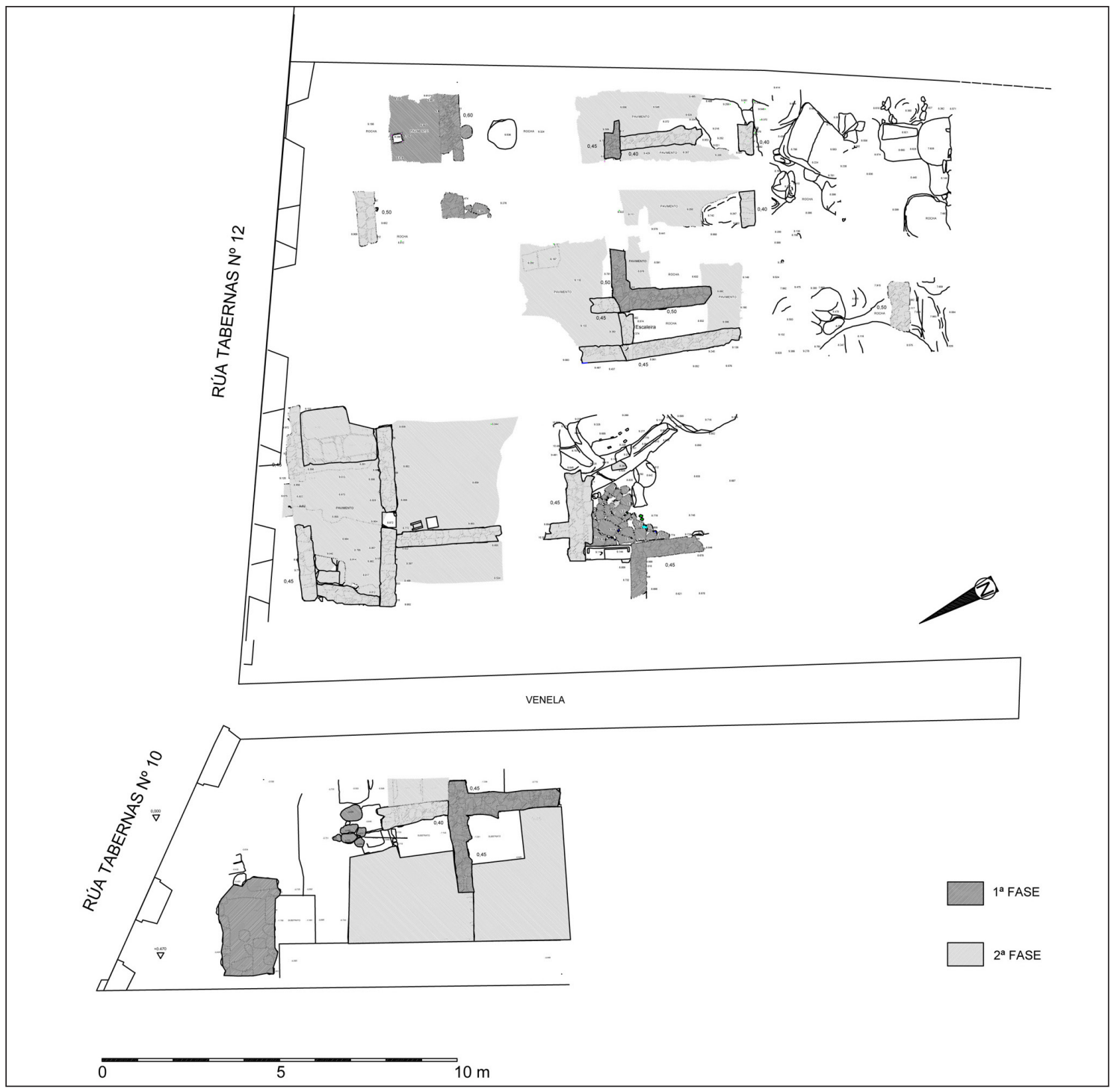

Figura 6. Plantas dos solares Tabernas 10 e 12 (TOMÁS BOTELLA 2003a; 2003b).

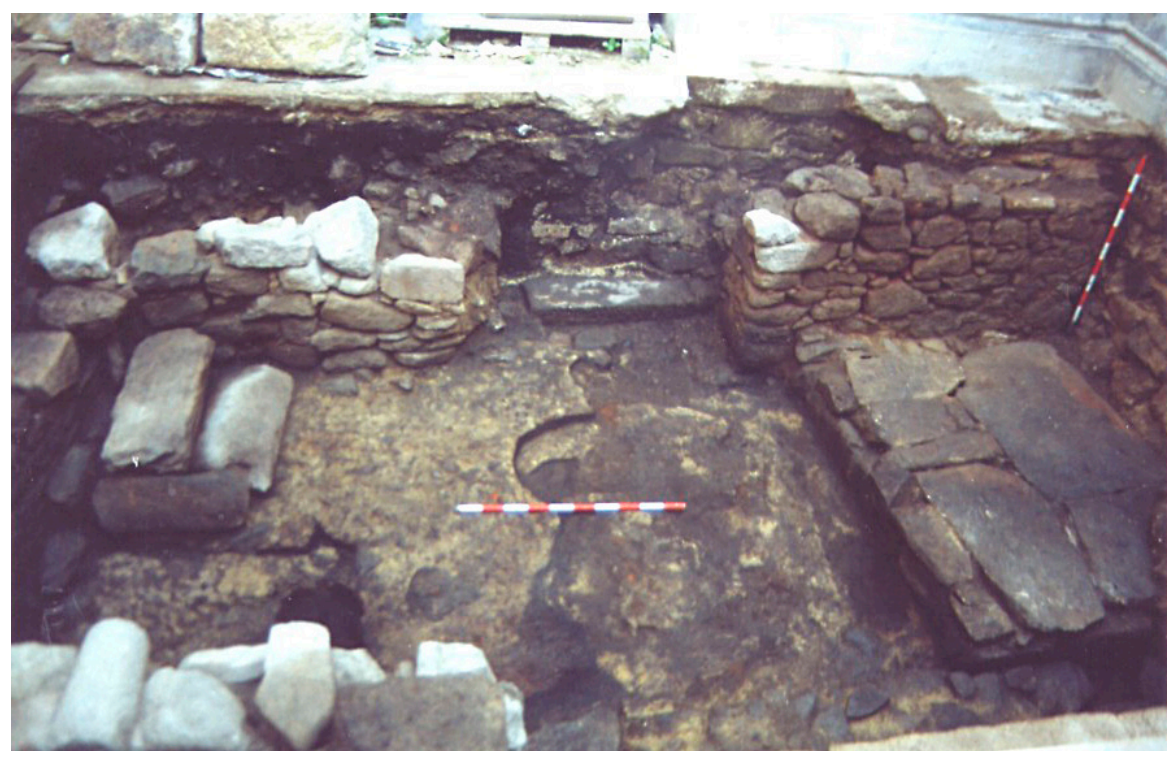

Figura 7. Estancia interpretada como cociña en Tabernas 12 (TOMÁS BOTELLA 2003a; 2003b). 
Continuando a través da rúa Tabernas, no $\mathrm{n}^{0} 18$ documentouse un nivel tardorromano, cun nivel de uso situable en torno ao s. IV a.c., relacionado cunha construción realizada a cachotería irregular, e cun pavimento asociado de terra pisada no exterior da edificación (RAMIL GONZÁLEZ 2009b). Do mesmo xeito ca nos casos anteriores, tamén atopamos indicios dunha ocupación anterior, como é o caso dunha ara adicada a Júpiter reutilizada na construción do muro que poderiamos datar dos s. I-II d.C. e dun pavimento de opus signinum de posible adscrición altoimperial (RAMIL GONZÁLEZ 2013: 112-113), que nos podería indicar unha reutilización e reconstrución da estrutura en época baixoimperial.

No inmoble inmediatamente contiguo, Tabernas 20, realizáronse varias sondaxes que exhumaron dous niveis de ocupación con características semellantes aos das anteriores intervencións (TOMÁS BOTELLA 2008a). Centrándonos na fase baixoimperial, este consta de varias estruturas asociadas, cun gran conxunto de materialidade baixoimperial dos que destacamos numerosos fragmentos de sigillata hispánica tardía asociados (TOMÁS BOTELLA 2008a). Baixo este nivel, documéntanse varios depósitos de época altoimperial, posiblemente vertedoiros, con abundante presenza de ánforas e cerámica común.

Así mesmo, podemos destacar algunhas obras con datos de menor entidade, como poden ser as sondaxes en Tabernas 4, que documentaron, ademais de materiais de adscrición romana en niveis de recheo, restos dun pavimento de opus signinum (LÓPEZ 2003). Na intervención de 2002 nos solares Tabernas $n^{0} 2$ e Santiago $n^{0}$ 6, tamén se atoparon materiais romanos en niveis de recheo, así como a existencia dunha construción de adscrición romana, sen niveis de ocupación conservados, posiblemente porque é reaproveitada como cimentación para unha construción de época moderna (RAMIL GONZÁLEZ 2003). Por último, no inmoble número 21 da rúa Tabernas documentáronse os dous niveis de ocupación xa habituais nesta zona, destacando unha construción de época tardorromana con abundante cerámica común e cerámica fina de mesa (TOMÁS BOTELLA 2005a).

A veciña rúa do Parrote tamén ofrece resultados interesantes, aínda que en menor cantidade. Nas intervencións realizadas en Parrote 14 (TOMÁS BOTELLA 2007b; TOMÁS BOTELLA 2010) documentáronse varias estruturas romanas, destacando a existencia dunha edificación con empedrado e un pozo, colmatado cun recheo de terra con cerámicas e restos anfóricos de adscrición romana (TOMÁS BOTELLA 2007). As cronoloxías desta estrutura son difíciles de definir, aínda que no inmoble inmediato, Parrote 16, documentouse un vertedoiro de cronoloxías romanas, con gran cantidade de sigillata hispánica tardía nos niveis de recheos superiores (MUÍÑO MANEIRO 2008a), posiblemente asociado coas construcións contiguas.

Na rúa Damas tamén atopamos información relevante. Na intervención realizada no inmoble $\mathrm{n}^{\mathrm{o}} 3$, exhumouse un muro e un pavimento de xabre con cronoloxías situables entre mediados-finais do I d.C. e comezos do II d.C. (MUíño MANEIRO 2008b). Nas intervencións realizadas en Damas 6 (FERNÁNDEZ RODRÍGUEZ 2000a; 200ob) resulta sinalable a aparición dunha estrutura pétrea de canalización de cronoloxías romanas, composta por dúas ringleiras paralelas de pedras ben careadas e de boa factura, posible- 
mente asociada a labores de drenaxe. Aínda que na primeira intervención o conxunto material semellaba levarnos a épocas baixoimperiais (FERNÁNDEZ RODRÍGUEZ 2000a), na segunda documentouse o nivel de uso desta estrutura de canalización, asociada a sigillatas hispánicas, restos anfóricos e cerámica común con decoración en retícula bruñida (FERNÁNDEZ RODRÍGUEZ 200ob), que semella máis axeitado datar en torno ao s. II d.C. O nivel baixoimperial anteriormente citado trataríase dun nivel de abandono homoxéneo que colmataría esta canalización, selado á súa vez por un empedrado de cronoloxías posteriores (FERNÁNDEZ RODRÍGUEZ 200ob).

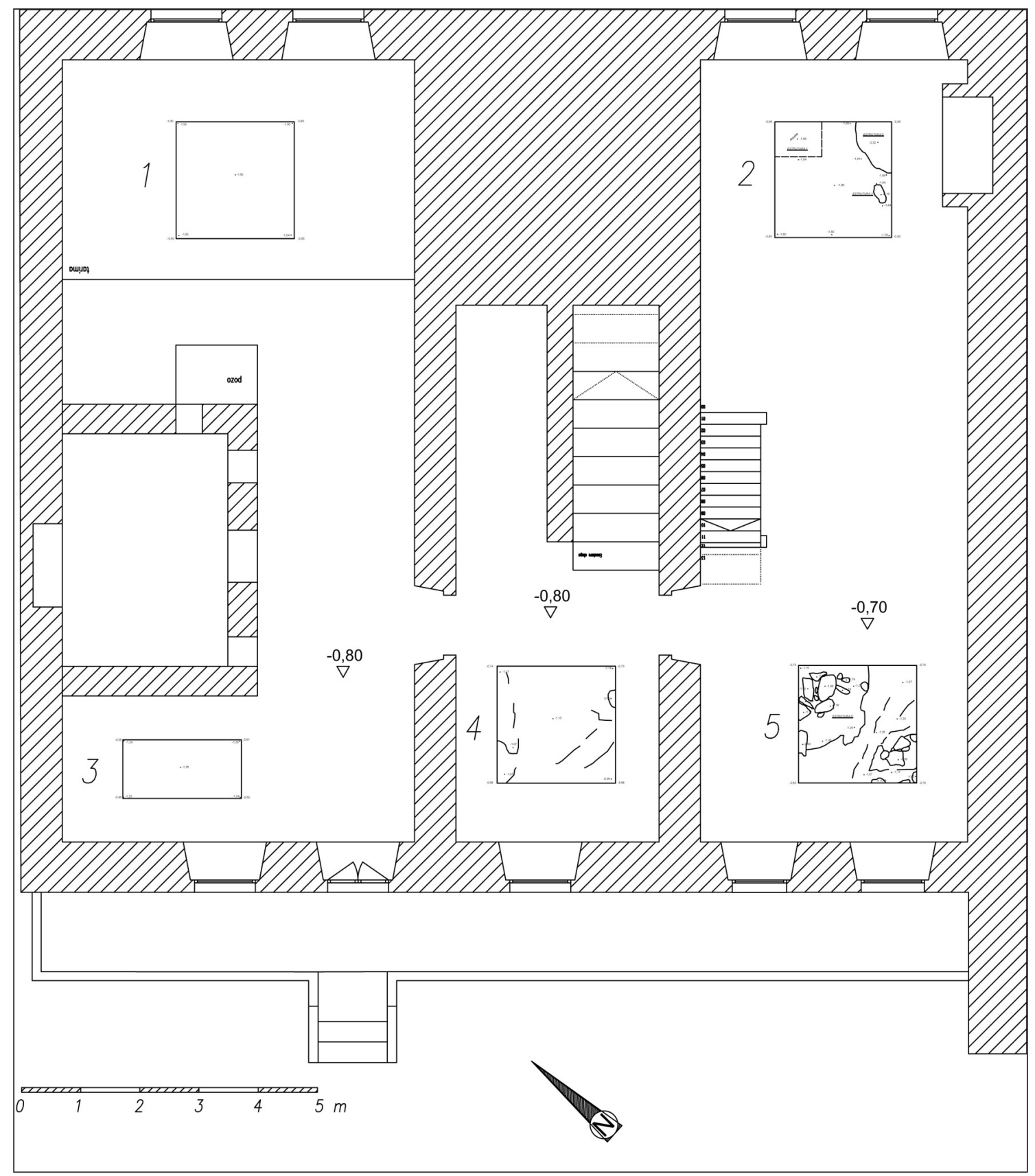

Figura 8. Planta e distribución das sondaxes en Parrote 14 (TOMÁS BOTELLA 2007b). 
Máis coñecidas son as intervencións realizadas en Damas 8, tratadas en recentes publicacións (LÓPEZ PÉREZ e MUÍ̃̃O MANEIRO 2011). Tras unha primeira actuación que deu como resultado a aparición de materiais romanos romana en posición secundaria (MUÍÑO MANEIRO 2003a), optouse por unha escavación en área da totalidade do solar (MUÍÑO 2003b, LÓPEZ PÉREZ e MUÍÑO MANEIRO 2011). Esta actuación exhumou unha pequena construción en ángulo, cortada polo muro medianeiro dunha construción posterior. Esta relacionaríase cunha construción adosada, con técnicas construtivas idénticas, e cunha foxa triangular escavada no substrato e con varios buratos de poste achegados, situada na súa contorna inmediata e na mesma unidade estratigráfica (MUÍÑO MANEIRO 2003b). A este conxunto hai que engadirlle dous depósitos secundarios situados fóra dos límites do inmoble, que aportan a gran maioría da colección cerámica estudada (LÓPEZ PÉREZ e MUÍ̃̃O MANEIRO 2011: 130). Aínda que se recuperan algúns materiais datables no I d.C. en niveis de recheo, a gran maior parte do conxunto pertence ao s. II d.C. (LÓPEZ PÉREZ e MUÍÑO MANEIRO 2011: 133), así como algúns materiais que se poderían datar en época baixoimperial, sempre en posición secundaria e relacionados co nivel de recheo que enche a citada foxa.

Figura 9. Planta do inmoble e sondaxes realizadas en Damas 8 (LÓPEZ PÉREZ \& MUÍÑO MANEIRO 2011: 128).

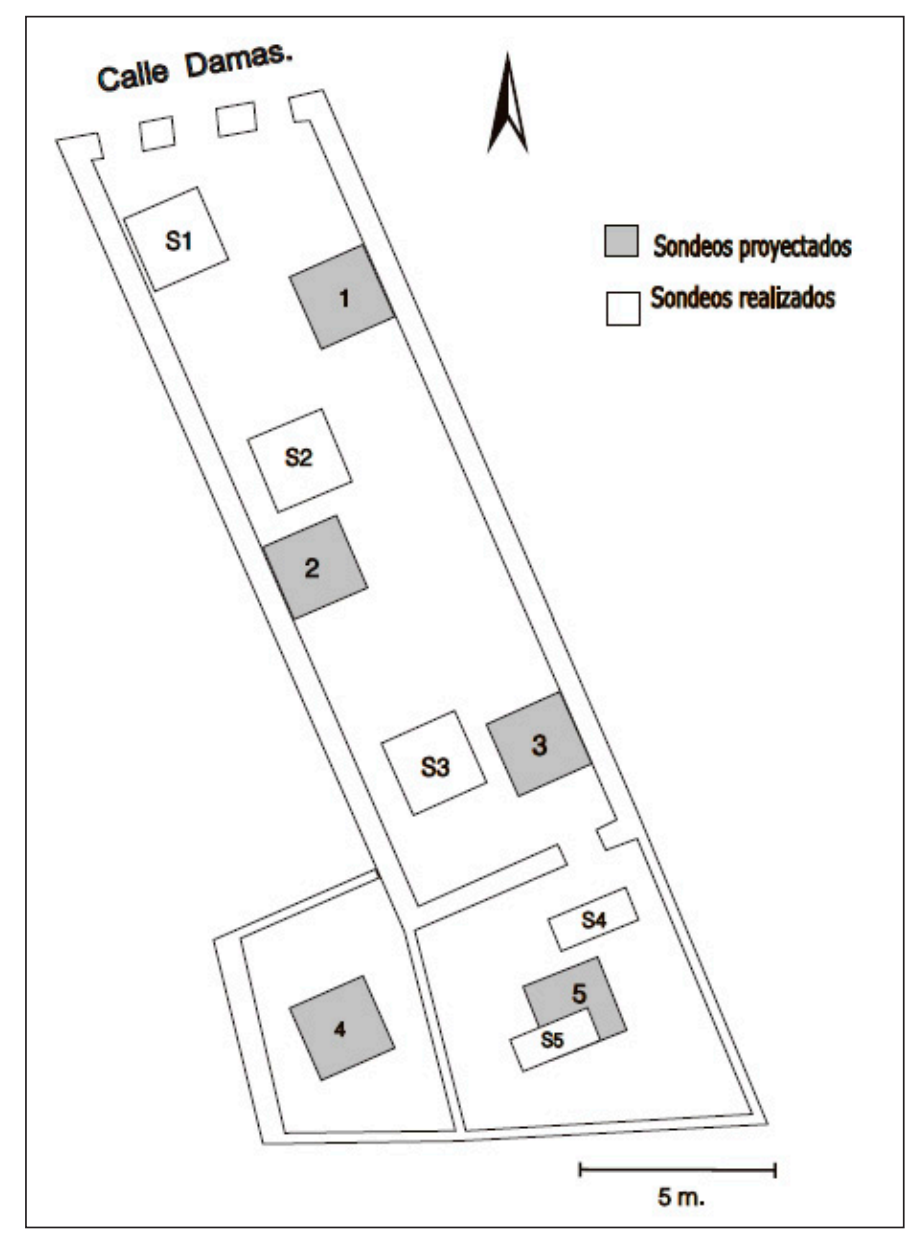

Os datos arqueolóxicos noutras zonas da Cidade Vella son bastante máis exiguos. No $\mathrm{n}^{0} 17$ da rúa Amargura, atopáronse, en niveis de recheo, fragmentos de terra sigillata hispánica e de verniz vermello pompeiano (TOMÁS BOTELLA 2006a). Este conxunto 
material resulta asimilable ao documentado no $\mathrm{n}^{0} 7$ da mesma rúa, engadindo ao xa citado unha gran cantidade de fragmentos de cerámica común romana (CCR de Alcorta e retícula bruñida) (CASTRO PAREDES 2002). Este tipo de achados en contextos secundarios son relativamente habituais, e as súas circunstancias contextuais son extrapolables a boa parte da zona vella. En Príncipe 17, documéntanse grandes cantidades de cerámica común romana e material anfórico en dous niveis superpostos de recheo (TOMÁS BOTELLA 2007a); no inmoble Porta de Aires 9 - Ferrerías 2 recuperáronse varias tégulas con pestana e un catillus de muíño reutilizado (PENA BASSO, 2010a); en San Carlos 3-5-7-9 recuperáronse restos de ánforas Almagro 51 e varias metas de múño (PRADO FERNÁNDEZ 2006a). Estas características deposicionais son extrapolables a outras rúas, con múltiples exemplos (RAMIL GONZÁLEZ 2001; 2006; PRADO 2008a) que non aportan moita máis información da xa comentada.

A única excepción ofrécea a intervención realizada na rúa Santo Domingo, ${ }^{0} 6$ (VIDAL CAEIRO 2006; 2009). Realizada entre 2005 e 2006, aporta o maior rexistro material documentado en toda a zona PEPRI, cun total duns 16 ooo fragmentos cerámicos e 800 obxectos metálicos, na súa maioría bronces, destacando unha gran cantidade de alfinetes e de 51 numismas de múltiples cronoloxías. Aínda que boa parte do conxunto debe situarse en época medieval, destacamos tamén a aparición de varias estruturas de época romana, conformando un conxunto construtivo composto por varios muros, algúns con enlousados asociados (VIDAL CAEIRO 2009: 35). A gran maioría do conxunto pódese datar en época altoimperial, iniciándose ao longo do s. I. Estas construcións, como acontece noutros casos desta mesma rúa, son abandonadas en época baixoimperial, con escasas evidencias de reocupación. A gran maioría de niveis posteriores ao s. III limítanse a un par de muretes de mala factura e varios estratos con deposición secundaria de materiais. Resulta interesante a aparición dun numisma de Galieno (datable entre o 260 e o 268 d.C.) nun destes niveis de depósito (VIDAL CAEIRO 2006: 12).

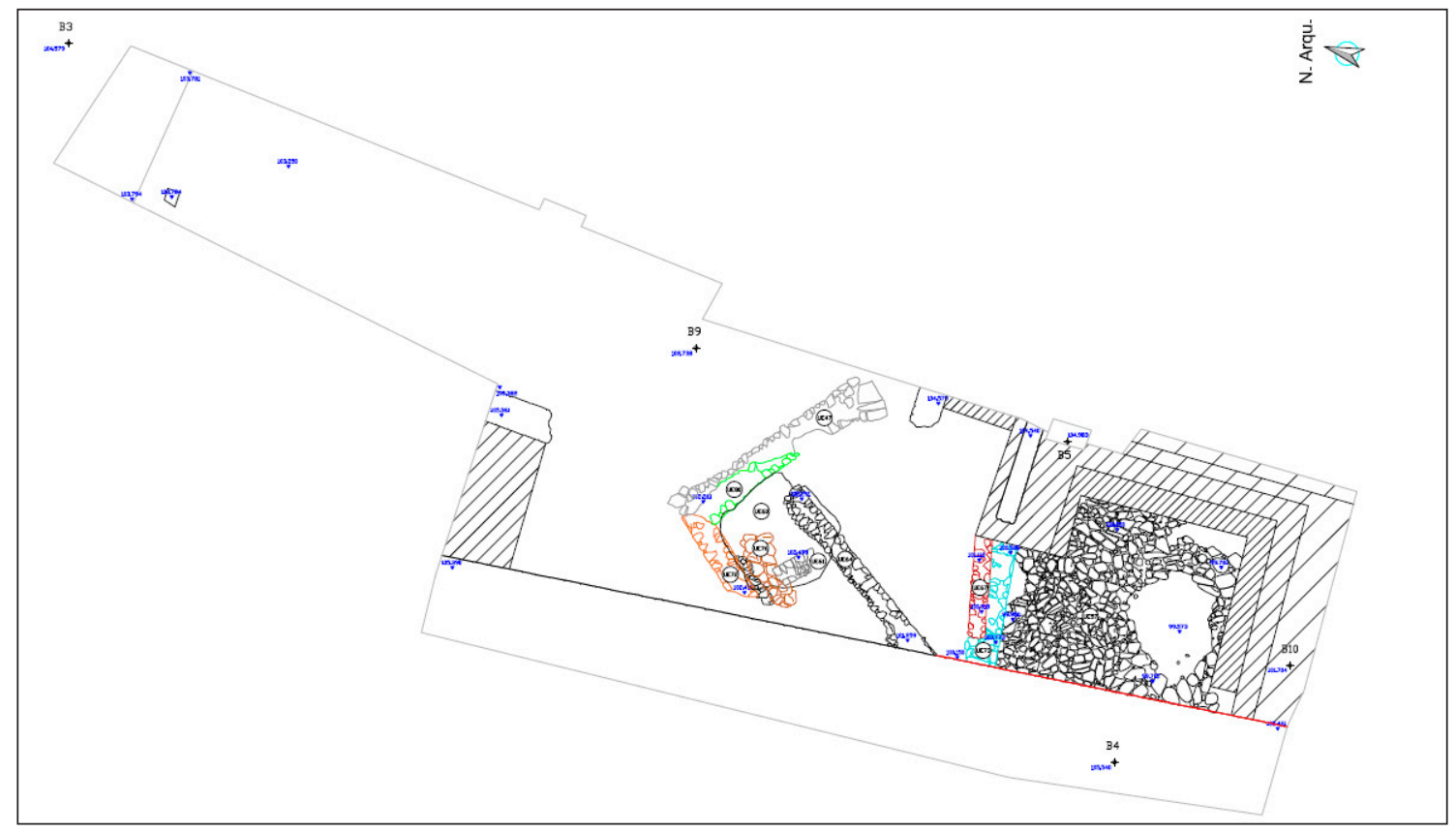

Figura 10. Estruturas romanas en planta documentadas en Santo Domingo 6 (VIDAL CAEIRO 2009). 


\section{Pescadería}

A zona denominada como barrio da Pescadería foi habitualmente considerada como a zona "de expansión" do núcleo orixinal romano de Brigantium, outorgándolle en ocasións cronoloxías posteriores ás da Cidade Vella (NAVEIRO LÓPEZ 1988: 45; LÓPEZ PÉREZ 2010: 97). A zona presenta un trazado case ortogonal que podería asociarse cun trazado "pseudohipodámico" (PÉREZ LOSADA 2002: 121), aínda que tampouco tería por que afastarse demasiado do urbanismo tradicional de moitas vilas mariñeiras galegas. Trátase da zona máis fértil a nivel de rexistro de todo Brigantium, cuns procesos postdeposicionais máis "benévolos" ca os da Cidade Vella. A Pescadería artéllase en torno a varias rías paralelas entre si, entre a Avda. da Mariña e a rúa de San Andrés. De forma aproximada, a súa extensión E-W poderíase situar entre os eixos Praza de María Pita-Rúa Nova, tendo como límite $\mathrm{N}$ a rúa de San Andrés.

Comezando en dirección E-W, a zona máis achegada á Cidade Vella é a Praza de María Pita, que xa foi froito de intervencións arqueolóxicas en 1985 (NAVEIRO LÓPEZ 1985, 1988). Na zona, moi arrasada por edificacións modernas e contemporáneas (NAVEIRO LÓPEZ 1985), aínda resulta posible atopar restos arqueolóxicos, sobre todo na parte $\mathrm{W}$ da praza (TOMÁS BOTELLA 2004d). Un bo exemplo é o pavimento de opus signinum documentado no seu número 22 (TOMÁS BOTELLA 2004d), estrutura delimitada por unha edificación da que apenas conservamos un par de fiadas da súa cimentación.

Son moito máis fértiles, por outra parte, os niveis arqueolóxicos das rúas situadas ao W da praza municipal. No número 4 de Riego de Agua, documentouse outra estrutura de opus signinum, sobre a que se sitúa unha estrutura cuadrangular de 80 x $90 \mathrm{~cm}$, conformada por pedras de granito de pequeño e mediano tamaño, de funcionalidade descoñecida (RUPIDEIRA GIRALDO 2001). Moi achegado a este pavimento, documentouse unha estrutura feita en barro, probablemente un escalón. Nas sondaxes previas a esta escavación en área xa se exhumara unha estrutura de canalización duns $2 \mathrm{~m}$ de longo, de forma rectangular e de cara lisa (RUPIDEIRA GIRALDO 2000). Este conxunto pode datarse en época altoimperial, atendendo á sigillata hispánica e aos fragmentos de verniz vermello pompeiano documentados en niveis de ocupación (RUPIDEIRA GIRALDO 2000).

Temos outros exemplos de construcións romanas nesta mesma rúa. No número 38 , recuperáronse varios treitos de muro, algúns con enlousado asociado (CASTRO VIGO 2009; 2010a), que semellan formar parte dun mesmo conxunto doméstico de cronoloxías altoimperiais. No número 40 documentouse a existencia dunha construción de época romana de cronoloxías indeterminadas que constaría dunha canle construída a partires de dous bloques de granito, integrada dentro da cimentación do edificio (GONZÁLEZ FERNÁNDEZ 200ob). O arqueólogo director sitúa esta edificación en época baixoimperial.

Resulta especialmente interesante a intervención realizada en Riego de Agua 56. A escavación en área realizada neste solar ofreceu unha cantidade inxente de información de múltiples cronoloxías. Moi achegada ás intervencións realizadas con anterioridade por Luengo Martínez en 1949 e Vázquez Gómez en 1991 (LUENGO 1953; BELLO DIÉ- 
GUEZ e VÁZQUEZ GÓMEZ, 1995: 34-35), esta actuación confirmou boa parte da información apuntada nestas dúas campañas. En primeiro lugar, destacamos a aparición de 8 sepulturas de inhumación de época baixoimperial, realizadas tanto en tégulas como con laxes de pizarra (PENA BASSO 2008a). Este último tipo de tumbas adoita asociarse tipolóxicamente con contextos altomedievais (NAVEIRO LÓPEZ 1988: 40), mais existen algúns exemplos que poderían datarse entre os s. IV-V d.C. (GONZÁLEZ VILLAESCUSA 2001: 101-103). Este tipo de paralelos resultan bastante axeitados, pois as tumbas 4 e 5 (esta última construída con laxas de pizarra) sitúanse no estrato superior ao que acolle unha construción muraria romana ${ }^{2}$, que sería amortizada para a construción dunha rampla con argamasa que comezaría no peche $\mathrm{N}$ do muro e que se estendería ata a altura das tumbas 4 e 5 (PENA BASSO 2008a). Esta construción resulta claramente anterior á construción da rampla, que á súa vez é anterior ás tumbas. Aínda que non temos datos materiais especialmente significativos, resulta bastante probable que esta construción poida situarse en época altoimperial, sendo a rampla un engadido posterior. As tumbas, tanto as de tégulas como as de laxes de pizarra, situaríanse nun nivel superior, nun nivel asimilable a época baixoimperial.

Paralela á Riego de Agua, a rúa Franxa xa ofrecera con anterioridade unha boa cantidade de materiais e estruturas arqueolóxicas (BELLO DIÉGUEZ 1991: 79-80; BELLO DIÉGUEZ e VÁZQUEZ GÓMEZ 1994: 34-35; VÁZQUEZ GÓMEZ 1996: 411-461), na gran maioría asociadas a unha fase de ocupación datable entre os s. I e II d.c (PÉREZ LOSADA 2002: 128). En boa parte das actuacións recentes documentáronse unicamente materiais en niveis de revolto (TOMÁS BOTELLA 2001c; VÁZQUEZ COLLAZO 2003; TOMÁS BOTELLA 2006b), mais podemos identificar algúns restos arqueolóxicos en posición primaria:

No inmoble $n^{0} 39$ da rúa Franxa, documentáronse dous treitos de muro cun pavimento asociado realizado con area de xabre e anacos de tégula pouco triturada (DOVAL GALÁN 2000a; 200ob). O conxunto material asociado é claramente tardoimperial, destacando a presenza de sigillata hispánica tardía, sigillatas africanas ou ánforas de tipoloxía Almagro 51 que permiten situar este conxunto entre os s. III-IV (DOVAL GALÁN 200ob), aínda que algúns materiais poderían estenderse temporalmente ata os s. V ou incluso o VI.

En Franxa 54, documéntanse dúas fases construtivas romanas claramente diferenciadas. Na primeira fase de ocupación, exhumouse unha canle arquitectónica en tegulae, cun marcado buzamento cara o SE, con materiais que nos levan aos S. I-II d.C. (sigillata hispánica, paredes finas, etc.) (TOMÁS BOTELLA 2001d). Sobre esta canle documéntase unha pequena construción cadrada/rectangular, con orientación SW-NE e realizada en mampostería, que podería constar dunha posible escaleira de acceso a un andar superior (TOMÁS BOTELLA 2001d). Para a segunda fase de ocupación, atopamos unha sucesión de distintos pavimentos, coroados por un opus signinum, que amortizan os niveis anteriores a través de pedra e argamasas (TOMÁS BOTELLA 2001d). Ambas fases asócianse

2 Non obstante, non podemos descartar unha posible "coexistencia temporal" entre ambas tipoloxías durante os primeiros séculos da Idade Media, pois o espazo semella seguir sendo utilizado como necrópole. 
co que xa estamos comezando a apreciar como habitual dentro do entramado brigantino, unha primeira fase altoimperial que queda amortizada tras unha nova fase de ocupación baixoimperial, posiblemente iniciada na segunda metade do s. III, que semella indicarnos unha nova etapa da vila coruñesa.

Ao $\mathrm{N}$ destas dúas rúas, a ocupación é moito máis dispersa. As intervencións realizadas nas rúas Florida, San Agustín ou na Praza do Humor non ofreceron resultados positivos (TOMÁS BOTELLA 2005d; SINDE 2009; FERNÁNDEZ ABELLA 2013; por exemplo). As intervencións realizadas nesta zona son bastante escasas en número (temos datos dunhas dez intervencións), e coa excepción dun recheo moderno con materiais romanos documentado na Praza de San Agustín (NAVEIRO LÓPEZ 1988: 39), esta ausencia pode indicar o límite $\mathrm{N}$ da zona de ocupación, cunha hipotética presenza marxinal que probablemente deixase poucas pegadas na zona. Un argumento a favor trátase da tumba de tégulas documentada na rúa Florida (NAVEIRO LÓPEZ 1988: 39-40), que en lugar de tratarse dunha teórica expansión do espazo adicada á necrópole, semella ser, máis ben, un enterramento illado nunha área que xa rondaba os límites da zona de ocupación altoimperial, igualmente desocupada a nivel habitacional en época baixoimperial.

Seguindo o camiño que marca a rúa Riego de Agua, continuamos pola rúa Real, que ofrece un un gran volume de información. No $n^{\circ} 8$, no emprazamento do antigo Cine París, exhumouse un nivel datable entre os s IV e V d.C., atendendo ao material anfórico e á terra sigillata africana recuperada (TOMÁS BOTELLA 2000e). Documéntase unha estrutura con restos de enlousado, parcialmente destruído, que poderían ter continuidade coas estruturas atopadas por Luengo en 1949 (LUENGO MARTÍNEZ 1953: 415427; NAVEIRO LÓPEZ 1988: 40; PÉREZ LOSADA 2002: 130-131). As cronoloxías desta construción non resultan totalmente claras, aínda que o arqueólogo director opta por situala en época baixoimperial (TOMÁS BOTELLA 2000e).

A escasos metros do Cine París, realizouse unha intervención que podería dar continuidade tanto aos restos documentados nesta intervención como aos exhumados por Luengo a finais dos anos 40. Realizada no $n^{0} 9$ da rúa Galera, documéntase un nivel de area grisácea con materiais de adsrcición romana e gran número de pedras de cuarcita traballadas, que o arqueólogo director considera parte do conxunto construtivo escavado no inmoble do Cine París (VÁZQUEZ COLLAZO 2002a). Este nivel de derrubo tería cronoloxías altoimperiais, atendendo a varios elementos como os fragmentos da forma 27 de sigillata hispánica, datable entre o último terzo do s. I d.C. e finais do II d.C. (VÁZQUEZ COLLAZO 2002a), co que se complica a súa relación coas estruturas do Cine París: ou son construcións diferenciadas, ou estamos ante un derrubo de edificacións anteriores realizado polas construcións baixoimperiais. Tampouco podemos descartar, en todo caso, unha ocupación altoimperial para os restos do Cine París.

Por outra parte, en Real 34 exhumáronse unha inxente cantidade de restos funerarios en varias intervencións (TOMÁS BOTELLA 2001b; 2003c; 2004b). Nunha primeira fase de escavación, recuperouse unha foxa de incineración con restos humanos dentro dunha vasilla romana tipo Vegas 31 e fragmentos dunha ola de cerámica común O1 de Alcorta (TOMÁS BOTELLA 2001b). Este conxunto, selado por acumulación de area mariña, podería datarse entre os s. I-II d.C., sendo a primeira evidencia dunha necrópole 
anterior ao conxunto de tumbas de tégulas habitualmente documentadas. Nunha segunda fase documentaríanse unha maior cantidade de foxas, un total de catro, tres con urna e enxoval asociado, tamén de incineración (TOMÁS BOTELLA 2003c). Así mesmo, a estas hai que engadirlle unha tumba de inhumación de carácter infantil. Unha terceira intervención remataría por definir este conxunto ao documentarse dúas foxas máis, dúas tumbas máis de inhumación e unha estela funeraria (TOMÁS BOTELLA 2004b). En definitiva, temos un grupo de enterramentos funerarios formado por un total de oito foxas de incineración, tres de inhumación e unha estela funeraria. Os esqueletes documentados foron obxecto dun estudo antropolóxico no que se definiron un total de tres individuos (SERRULLA RECH 2004, GRANDAL D'ANGLADE et al. 2015). Dous estarían carbonizados ao ser cremados en urnas de incineración, mentras que o esquelete, en bo estado de conservación, pertence a unha muller de baixa estatura, falecida en torno aos 35 anos de idade, e de posible orixe norteafricano (SERULLA RECH 2004).

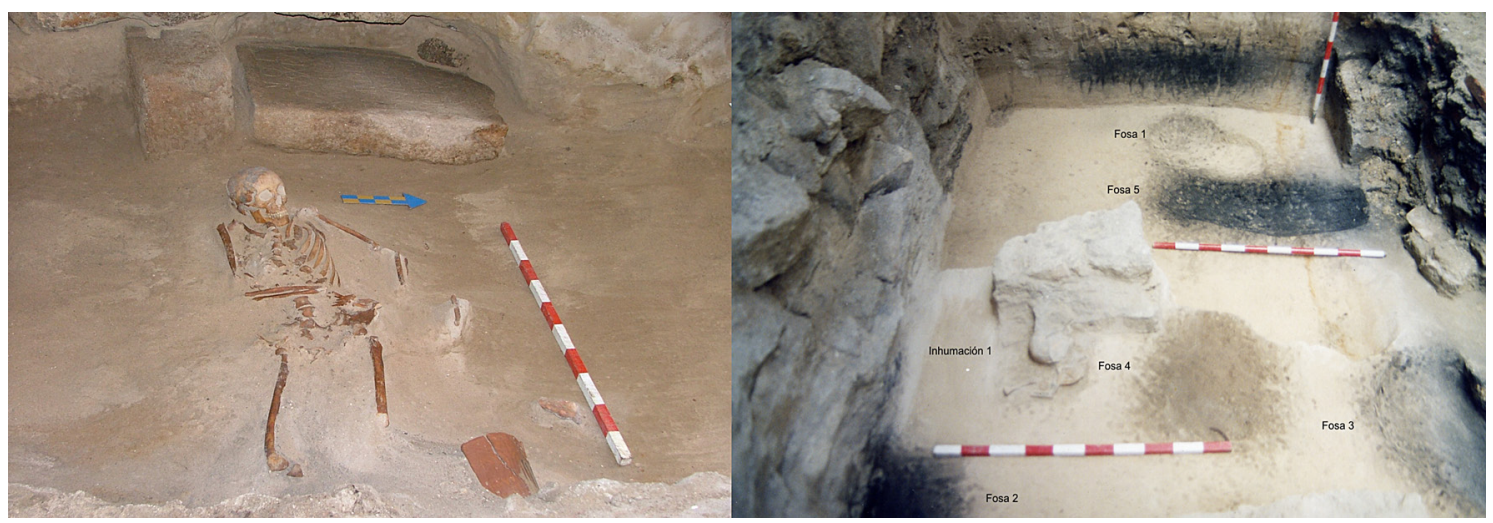

Figura 11. Inhumación nº 3 con lauda e sector E da necrópole de Real 34 (TOMÁS BOTELLA 2004b).

Esta intervención ofrece datos totalmente novidosos para a comprensión de Brigantium. A aparición de foxas de cremación con contextos asociados aos s. I-II d.C. permítenos datar as primeiras épocas de ocupación da necrópole da rúa Real. Ata este momento, todas as tumbas documentadas eran adscribibles a un período baixoimperial, pero a presenza destas novas tipoloxías de enterramentos indícanos que esta zona xa tiña uso como necrópole en tempos bastante anteriores (amosando tamén o habitual polimorfismo tipolóxico ben coñecido nos enterramentos altoimperiais). Por outra parte, a aparición dunha estela funeraria que alude á presenza dun exactor en Brigantium volve incidir na relevancia do enclave como lugar administrativo. Este epígrafe, recentemente estudado (RODRÍGUEZ COLMENERO 2005), indícanos a máis que probable existencia dunha statio do portorium en Brigantium, tal e como se ten comentado anteriormente (BALIL ILLANA 1977: 123-129; BELLO DIÉGUEZ 1991: 91; NAVEIRO LÓPEZ 1994: 38; PEREIRA MENAUT 1994; RODRÍGUEZ COLMENERO 2005: 883; LÓPEZ PÉREZ 2010: 99), un punto de cobro que incidiría na importancia da administración imperial na estruturación urbana da vila. 


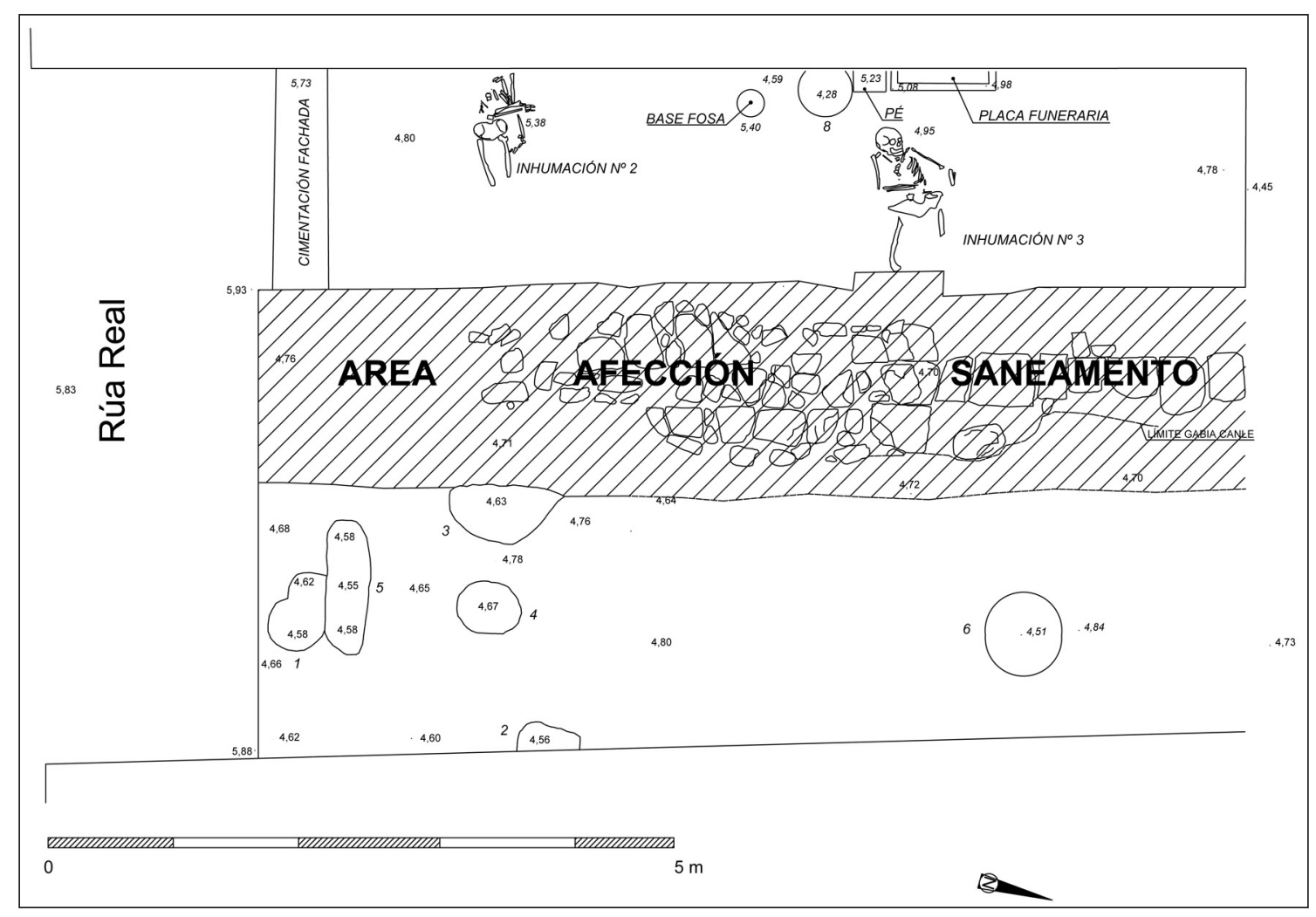

Figura 12. Detalle da planta da intervención en Real 34 (TOMÁS BOTELLA 2004b).

Se continuamos en dirección W pola rúa Real, semella plausible que a necrópole tivese os seus límites en torno aos $\mathrm{n}^{0}$ 40-50 de devandita rúa. Na intervención realizada en Real 56, documentouse un pavimento de opus signinum con dúas fases construtivas, así como unha gran cantidade de tégula en niveis de recheo (LÓPEZ 2005). Máis adiante, no n ${ }^{0} 67$, documéntase material cerámico romano moi rodado, así como restos dun pequeño concheiro (TOMÁS BOTELLA 2004c), duns 0,3 $\mathrm{m}^{2}$ de superficie, de probable orixe doméstica e interpretado como un espazo marxinal situado na contorna urbana (TOMÁS BOTELLA 2004c).

Na rúa Galera, non obstante, apenas atopamos restos arqueolóxicos (BLANCO SANMARTÍN 1999, TOMÁS BOTELLA 200oh; 2007i; PRADO FERNÁNDEZ 2007), coa excepción das estruturas xa comentadas anteriormente (VÁZQUEZ COLLAZO 2002a). Esta ausencia continua en todas as zonas analizadas situadas ao W da rúa Bailén, na que desembocan Franxa e Riego de Agua. En todas as intervencións situadas entre as rúas San Andrés, Bailén-Barreira, Galera e Nova (un total de 22), unicamente documentáronse restos arqueolóxicos en dúas: o xa comentado caso do $n^{0} 9$ da rúa Galera (posiblemente parte do conxunto de Real 8 e moi achegado á zona urbanizada da Pescadería), e un pequeno compendio de materiais composto por un pequeño fragmento de sigillata hispánica e restos dunha ánfora oriental dos s. V d.C., presentes nun nivel de recheo exhumado no $\mathrm{N}^{0} 32$ da rúa Barrera no que predominan as cerámicas esmaltadas medievais (PRADO FERNÁNDEZ 2006c). Todo indica que estamos ante un caso semellante ao das rúas Florida e San Agustín, cunha presenza de niveis de ocupación antiga nula e unha 
presenza material moi escasa, o que nos amosa o límite $\mathrm{N}$ da ocupación galaicorromana nesta zona.

\section{Zalaeta-Orillamar}

Nos barrios de Zalaeta e Orillamar foron revisadas un total de 23 intervencións, das cales ningunha ofreceu evidencia de ocupación antiga na zona. Esta ausencia de restos arqueolóxicos segue a liña do apuntado anteriormente, na que se plantexaba unha ocupación nula ou marxinal dende San Agustín cara o Norte. Cos datos dos que actualmente dispoñemos, podemos concluír que esta área carece de ocupación en época antiga.

\section{Cantóns-Orzán}

Situación distinta é a que ofrece a zona situada ao W da rúa Nova. No espacio situado máis ao N (nas rúas Orzán, Hortas, Santa Catalina e San Andrés) non se documentan materiais nin estruturas das épocas que nos atinxen (PARGA CASTRO 2002; TOMÁS BOTELLA 2003d; PRADO FERNÁNDEZ 2008c), atendendo aos resultados dunhas 12 intervencións analizadas, situación que cambia bastante a medida que nos aproximanos á zona dos Cantóns.

O principal achado documentouse nos $n^{0}$ 21-28 do Cantón Grande, nos que se realizaron múltiples intervencións para a construción da sé da Fundación Caixa Galicia. As primeiras intervencións neste inmoble xa foron brevemente documentadas nas últimas sínteses realizadas sobre o poboamento brigantino, nas que se comentaba brevemente as súas inusuais características (PÉREZ LOSADA 2002: 109-140; LÓPEZ 2004: 48-72). Relativamente afastada do núcleo central da zona de Pescadería, este espazo ofreceu, baixo os muros medianeiros, unha posible villae con planta en $\mathrm{U}$, cun patio central ao W do cal se adosarían as diferentes estruturas habitacionais e produtivas do edificio (VÁZQUEZ COLLAZO 1998a; 1998b; 1999a). A través de diversas intervencións, documentaríanse máis datos desta edificación, como a presenza de múltiples pavimentos de opus signinum de boa factura, as características de múltiples estruturas adosadas a unha construción central ou a existencia dunha pequena foxa circular de carácter singular situada baixo un preparado de opus signinum, tegulae colocadas e area (VÁZQUEZ COLLAZO 1999a). Este burato, atendendo á interpretación do arqueólogo director, sería un posible elemento ritual asociado cun rito fundacional do edificio (VÁZQUEZ COLLAZO 1999a). Así mesmo, no relativo ás estancias, resulta complicado definir a súa funcionalidade. A nivel xeral, na estancia 2 documéntase unha lareira, mentres que na 3 aparece a base dun forno feito con dúas grandes tégulas. A estancia 5 é un patio exterior, mentres que a 6 podería ter a mesma funcionalidade. A existencia de materiais como escouras de ferro en determinadas áreas do edificio (VÁZQUEZ COLLAZO 1998a; 1998b) fainos pensar tamén nunha posible especialización produtiva en determinadas zonas. Así mesmo, a diferente preparación dos solos en función dos espazos amósanos gran coidado por amoldar cada espazo ás actividades realizadas (VÁZQUEZ COLLAZO 1999a). 
A nivel xeral, podemos destacar a existencia de numerosos elementos característicos das villae, como é a existencia de múltiples estancias asociadas, a boa calidade do aparello dos muros, a existencia de múltiples elementos decorativos (como é o caso dos enlucidos pintados con decoracións xeométricas) ou a existencia de elementos construtivos como basas de columnas ou capiteis (VÁZQUEZ COLLAZO, 1999a).

No referido ás súas cronoloxías, o certo é que o seu conxunto intégrase ben en época baixoimperial, algo que cadraría coa súa adscrición como villae, tal e como propón o arqueólogo director en varias ocasións (VÁZQUEZ COLLAZO 1998a; 1998b; 1999s). Se atendemos aos estudos das súas sigillatas, realizado por López Pérez, vemos como unha gran parte do conxunto débese datar en épocas baixoimperiais, cunha relevante presenza de hispánica tardía, focense tardía e africanas claras (LÓPEZ 2004: 68-69).

Porén, este estudo tamén evidencia a existencia de materiais anteriores, como é o caso da forma 29 con decoracións metopadas, e outras pezas como a 15/17 de cronoloxías máis vagas pero que non adoitan superar o s. III d.C. (LÓPEZ PÉREZ 2004: 188-190). De feito, a propia autora cita como cronoloxía máis probable de fundación para os primeiros momentos de ocupación deste espazo os últimos anos do s. I d.C. (LÓPEZ PÉREZ 2004: 69). En todo caso, aínda que poida resultar inusual a existencia dun xacemento altoimperial tan afastado do núcleo central da Cidade Vella-Pescadería, non parece improbable que existisen edificacións preto do teórico camiño de acceso á urbe, que se situaría bastante achegado a esta construción (PÉREZ LOSADA 2002: 131). Por outra parte, a interpretación deste espazo como villae, non implica que tivese estas características dende os comezos da súa ocupación, sendo probablemente reutilizada, reformulada e dotada dun novo sentido co paso dos anos, tal e como acontece con boa parte das construcións documentadas en Brigantium. Esta reformulación é apreciable en determinas zonas do edificio, como as estancias 3 e 4 (VÁZQUEZ COLLAZO 1999a). Esta interpretación tampouco nega que tivese unha actividade relevante a nivel económico con anterioridade, como se ten proposto (BELLO DIÉGUEZ 2008: 63), o que resulta coherente cos datos dos que dispoñemos.

Para completar a información deste conxunto, resulta interesante atender as intervencións realizadas na súa contorna. En primeiro lugar, destacamos a aparición dun pozo circular, duns $90 \mathrm{~cm}$ de diámetro, cunha parede circular de 35-40 cm de grosor, que constaba dunha gran fondura (6,5 m respecto á cota do Cantón Grande), rematado por unha estrutura de madeira baixo a que se situaría unha base de pedras de $30 \mathrm{~cm}$ de grosor (VÁZQUEZ COLLAZO 1998c).

Destacamos tamén as intervencións realizadas no Cine Avenida (Cantón Grande $\mathrm{n}^{\mathrm{o}}$ 7, VÁZQUEZ COLLAZO 1999c), que definiron a ausencia de continuidade estrutural por esta zona, continuidade que si era apreciable cara a rúa Estrella. Tras a realización dunha intervención no seu $\mathrm{n}^{0} 23$, documentouse un gran aporte de material construtivo romano e cerámica común, concentracións de pedra de construción e restos de cerámica común (VÁZQUEZ COLLAZO 1999e). Con todo, o nivel de arrase impediu definir as súas características, sendo imposible establecer se se trataba do desmonte dunha estancia asociada, dunha construción diferente achegada a ela ou dun simple nivel de depósito. Esta edificación dos Cantóns si amosou continuar en planta cara a Fundación Barrié, 
sen que se puidese definir o final dalgunhas estruturas (VÁZQUEZ COLLAZO 1999d). Desgraciadamente, non se realizou (ou non consta) ningunha intervención relacionada coa construción da Fundación Barrié, polo que semella que estes restos nunca poderán ser recuperados.

Xa para rematar, os datos arqueolóxicos máis afastados do entorno de Brigantium atopáronse nos números 2 e 3 da rúa Sánchez Bregua (TOMÁS BOTELLA 2007l; 2008c; MARTÍNEZ CASAL 2009). Situados a uns $300 \mathrm{~m}$ ao SW das construcións dos Cantóns, estas intervencións tiñan como principal obxectivo a documentación dos sistemas defensivos propios da muralla da Coruña, en concreto o "Baluarte del Príncipe e o "Frente de Tierrra” (TOMÁS BOTELLA 2008c; MARTÍNEZ CASAL 2009). Así e todo, no no 3 atopáronse os restos da cimentación dun muro nun nivel claramente romano, con restos de terra sigillata, cerámica común e material latericio (TOMÁS BOTELLA 2008c). Este treito de muro pódese poñer en relación co exhumado no $\mathrm{n}^{0} 2$ da mesma rúa: restos doutro muro en mal estado de conservación dentro dun estrato con abundante material romano (material latericio, cerámica común e imitación de engobe vermello pompeiano). A aparición destes restos nun lugar tan afastado do "centro urbano" pon de manifesto dúas cousas. En primeiro lugar, semella confirmar os indicios aportados pola suposta villa documentada nos Cantóns, amosando unha zona de ocupación moito máis ampla da que anteriormente se consideraba. En segundo lugar, cómpre ter presentes os fragmentos de tégula recuperados por Luís Monteagudo no xardín da Rosaleda (BELLO DIÉGUEZ 1991: 83), localizados a escasos metros das intervencións realizadas. Este dato, que no seu momento semellaba unha mostra da ocupación moi afastada do núcleo central de ocupación, agora semella ter un contexto propio. Con todo, debemos analizar se este espazo realmente forma parte do núcleo central ou se forma parte dunha zona "periférica” cuxa extensión aínda está por determinar.

\section{O entramado "URbano" de Brigantium: eVolución E ORGANIZACIÓN INTERNA}

A información proporcionada por estes últimos vinte anos de arqueoloxía, como podemos ver, pode permitirnos analizar e comprender a evolución do emprazamento de Brigantium cun nivel de detalle moito maior. Como non podía ser doutro xeito, esta interpretación terá en conta á totalidade dos datos arqueolóxicos dispoñibles, non unicamente os anteriormente presentados.

$\mathrm{O}$ actual volume de datos arqueolóxicos permite a realización dunha aproximación máis detallada á organización interna de Brigantium, sobre todo se contrastamos esta información coa das intervencións realizadas con anterioridade. Nesta liña, o primeiro que debemos plantear é a necesidade de entender Brigantium non coma un conxunto uniforme que mantén inmutable os seus límites, funcionalidades e espazos durante época romana, tal e como se ven facendo (en boa medida propiciado pola limitación dada pola investigación arqueolóxica). Como veremos, durante estes case 400 anos a vila irá cambiando co paso do tempo, e semella ser un enfoque máis acertado analizar a súa organización atendendo a estas fluctuacións. 
Quizais resulte útil realizar unha pequena aproximación introdutoria para apreciar con claridade estas dúas fases de ocupación. A primeira fase, que podemos denominar altoimperial, podémola situar entre mediados do s. I d.C. ${ }^{3}$ e os primeiros anos do s. III d.C. A segunda fase podémola situar entre mediados e finais do s. III d.C., chegando posiblemente ata épocas ben avanzadas na tardoantigüidade (probablemente entre o V e o VI d.C.) que exceden os obxectivos desta investigación. Existe a posibilidade, como veremos máis adiante, de que entre ambos períodos exista un momento de "hiato", no que boa parte das construcións queden abandonadas, pois a continuidade estrutural entre construcións de ambas etapas non é demasiado habitual.

No caso da Cidade Vella, estas dúas fases son especialmente observables na rúa Tabernas. As estruturas e niveis altoimperiais son amortizados e utilizados como cimentación de novas construcións realizadas en época baixoimperial, posiblemente a mediadosfinais do s. III d.C. Para este exemplo, son especialmente significativos os datos obtidos nos inmobles $\mathrm{n}^{0} 10$ e 12 da rúa Tabernas (TOMÁS BOTELLA 2001a; 2002a; 2003a; 2003b) aínda que existen indicios en case todos os solares escavados. Este proceso tamén é apreciable nas poucas zonas con niveis arqueolóxicos da zona vella (VÁZQUEZ GÓMEZ 1995, FERNÁNDEZ RODRÍGUEZ 2000a; 200ob; MUÍÑO MANEIRO 2003a; 2003b; LÓPEZ PÉREZ E MUÍÑO MANEIRO 2011). Son especialmente significativos os exemplos de Damas 6, Damas 8 ou Santo Domingo 6, nos que existen materiais baixoimperiais en posición secundaria amortizando estruturas altoimperiais (FERNÁNDEZ RODRÍGUEZ 2000a, 2000b, MUÍNO MANEIRO 2008b, VIDAL CAEIRO 2009).

Este proceso tamén é apreciable na zona da Pescadería, aínda que neste caso cunha maior variabilidade. Nesta zona xa se teñen documentadas estruturas altoimperiais abandonadas en torno a estas épocas, moitas delas colmatadas por basureiros dos $\mathrm{s}$. III-IV (BELLO DIÉGUEZ 1991: 79-80; BELLO DIÉGUEZ e VÁZQUEZ GÓMEZ: 34-35; VÁZQUEZ GÓMEZ 1996: 416; PÉREZ LOSADA 2002: 128). Tamén observamos algúns casos de espazos reocupados e reformulados, como o no 54 da rúa Franxa (TOMÁS BOTELLA 2000g) ou o ${ }^{0} 56$ de Riego de Agua (PENA BASSO 2008a), aínda que neste caso o espazo deixa de ser habitacional para pasar a formar parte da necrópole. Outras edificacións como as documentadas en Franxa 39 (DOVAL GALÁN 2000a, 200ob) ou Riego de Agua 40 (GONZÁLEZ FERNÁNDEZ 200ob) son bos exemplos de construcións ex novo, con niveis datables a partires dos S. III-IV d.C. e sen ocupación anterior, incidindo nesta liña de renovación e reformulación de Brigantium en época baixoimperial.

A presenza destas dúas fases ben apreciables no rexistro e con suficiente información para definilas, obriga a que interpretación do Brigantium romano atenda a estas dúas fases de ocupación.

\section{Alto Imperio}

Resulta moi complicado definir cales son os primeiros momentos de ocupación para a península coruñesa, unha cuestión complexa que require un estudo a fondo que excede

3 Probablemente en torno ao 70 d.c., en contextos Flavios, seguindo os planteamentos de González García ou López Pérez (GONZÁLEZ GARCÍA 2003, 11, 259; LÓPEZ 2012, 97-99). 
os obxectivos desta publicación. Os últimos datos inciden no inicio do núcleo de poboación que coñecemos como Brigantium en torno á época Flavia (LÓPEZ PÉREZ 2012: 96-107), datas que semellan axeitadas para as primeiras construcións altoimperiais e para a primeira planificación do entramado brigantino (GONZÁLEZ GARCÍA 2003: 11, 259; LÓPEZ PÉREZ 2012: 97-99). Estas datas coincidirían, asemade, coas que actualmente se manexan para os inicios na construción da Torre de Hércules (LÓPEZ 2004: 65-67; BELLO DIÉGUEZ 2008: 63-64; LÓPEZ PÉREZ 2012: 102).

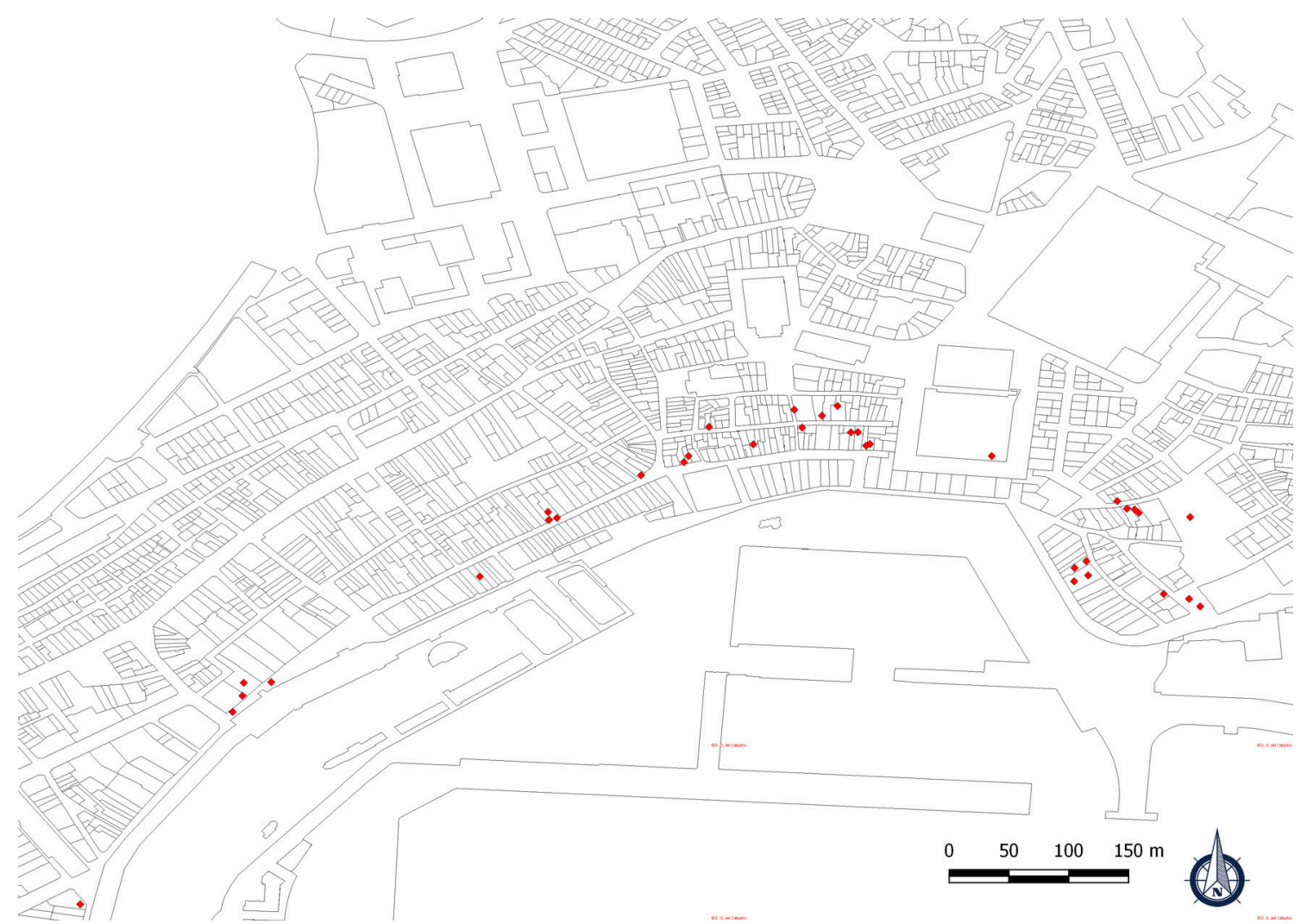

Figura 13. Niveis de ocupación con cronoloxías altoimperiais (I-II d.C.).

Atopamos niveis de ocupación asociados a estas cronoloxías ao longo de toda a Cidade Vella (FERNÁNDEZ 200ob; MUÍÑO MANEIRO 2003b; VIDAL 2006; 2009), como dixemos, moitas veces arrasados por construcións posteriores (TOMÁS BOTELLA 2001a; 2002a; 2003a; 2003b). Aínda que nunha boa parte da Cidade Vella non se documentan espazos con niveis de ocupación altoimperiais, o certo é que podemos asociar este asunto coa gran erosión á que se veu sometida a zona, cunha actividade humana case ininterrompida durante varios centos de anos sobre un solo con moi pouca potencia. Ademais, os solares con niveis de ocupación romanos amósannos unha intensa ocupación altoimperial que aparentemente semella estenderse por toda a zona.

A zona da Pescadería semella seguir un esquema semellante. Atopamos evidencias de ocupación altoimperial concentradas, sobre todo, nas rúas Riego de Agua e Franxa. Os límites da zona habitada parecen estar bastante ben definidos, tal e como apreciamos no mapa, existindo un límite N marcado polas rúas Galera, San Agustín e Florida, e un 
límite W delimitado pola necrópole. Cómpre deterse un momento neste punto, pois nestas cronoloxías, unicamente atopamos datos arqueolóxicos de enterramentos no punto das intervencións de Real 34 (TOMÁS BOTELLA 2001b; 2003c; 2004b), sen descartar que poida ocupar parte do espazo da necrópole posterior. En todo caso, a existencia dun probable derrubo de estrutura altoimperial na rúa Galera no 9 (VÁZQUEZ COLLAZO 2002a), así como a posible adscrición altoimperial das construcións do Cine París (Real $n^{0} 8$ ) indícannos a existencia dunha zona de ocupación nunha área que será utilizada como espazo de enterramento en época baixoimperial. O límite $\mathrm{W}$ da mesma semella situarse nos no 40-50 da rúa Real, a partir dos cales comezan a aparecer de novo estruturas habitacionais illadas (LÓPEZ 2005) ou depósitos secundarios de época altoimperial como o concheiro atopado do no 67 (TOMÁS BOTELLA 2004c). Esta zona semella ser xa o inicio da "periferia", e as poucas construcións documentadas comezan a situarse no teórico camiño de acceso ao centro da vila, como as estruturas documentadas nos Cantóns ou Sánchez Bregua 2 e 3 (VÁZQUEZ COLLAZO 1998a, 1999a, TOMÁS BOTELLA 2008c, MARTÍNEZ CASAL 2009), bastante afastadas do núcleo central. Estas zonas non semellan, aparentemente, ter unha continuidade urbana coas anteriores, ao situarse fóra do propio núcleo e máis aló de zonas de necrópole e vertedoiros. Os datos actuais indican que se tratan de espazos construtivos independentes, asociados ao camiño de acceso á vila e cunhas dinámicas sociais que poden diverxer lixeiramente das documentadas no centro.

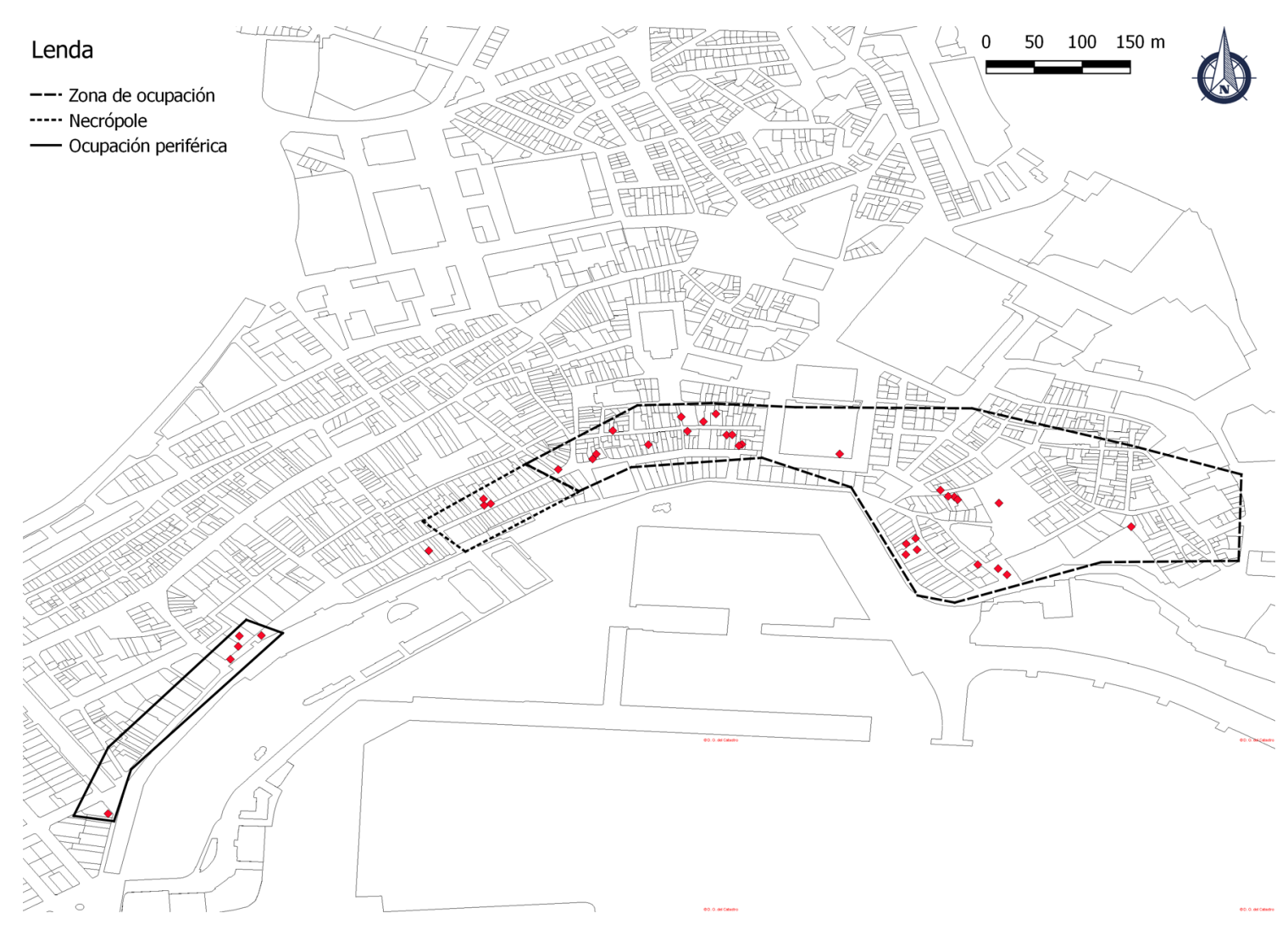

Figura 14. Brigantium en época altoimperial (I-II d.C.). 
O resto de límites do poboado semella ser máis ou menos común a ambas fases, atendendo ao estado actual da investigación: a rúa Maestranza na Cidade Vella, o espazo delimitado pola sé municipal do concello de A Coruña, San Agustín-Florida e a zona N da rúa Galera semellan ser un límite $\mathrm{N}$ común a ambas fases.

Así mesmo, debemos destacar que todo o conxunto urbano da Cidade Vella e Pescadería semella ser realizado ex novo, baixo unha mesma planificación urbana e en momentos relativamente sincrónicos, sen existir aparentemente diferencias temporais entre as construcións da Cidade Vella e a Pescadería.

\section{Baixo Imperio}

Definir os inicios do Baixo imperio resulta unha tarefa bastante complexa. Aínda que expuxemos con anterioridade a clara diferencia estratigráfica e estrutural entre ambos períodos, o certo é que non podemos afinar con exactitude o momento concreto no que Brigantium "rexurde", así como situar cronoloxicamente estes períodos de abandono e reformulación. Tendo en conta que dependemos da información da arqueoloxía de urxencia, resulta quimérico agardar datos de datacións radiocarbónicas, e os estudos de materiais tampouco permiten afinar demasiado este tipo de cronoloxías. Esta fase de posible abandono, citada nalgunha publicación anterior ${ }^{4}$ (NAVEIRO LÓPEZ 1988: 47) posiblemente se producise en torno ás décadas iniciais do s. III d, e semella non durar máis duns poucos anos. Tampouco estariamos ante unha desaparición total do núcleo poboacional, senón máis ben dunha desocupación parcial dunha gran parte da vila altoimperial. Tampouco semella que a poboación se "reubique" na Cidade Vella, como se ten proposto (LÓPEZ PÉREZ E MUÍÑO MANEIRO 2011: 133; LÓPEZ PÉREZ 2012: 103). Os datos arqueolóxicos son bastante significativos neste aspecto: tras esta teórica fase de abandono, apréciase unha fonda remodelación de zonas como Parrote ou Tabernas na zona Vella (TOMÁS BOTELLA 2002a; 2003b; 2007b; LÓPEZ PÉREZ E TOMÁS BOTELLA 2010), que coexisten de forma contigua xunto con espazos abandonados, como acontece nas rúas Damas e Santo Domingo (FERNÁNDEZ RODRÍGUEZ 200ob; VIDAL CAEIRO 2006; MUÍÑO MANEIRO 2008b; VIDAL CAEIRO 2009; LÓPEZ PÉREZ E MUÍÑO MANEIRO 2011). Pola súa parte, na Pescadería son bastante visibles varias construcións de cronoloxías claramente baixoimperiais. Algunhas estruturas altoimperiais caen en desuso en época baixoimperial, como as da Franxa 9-11 ou da Casa Martelo (BELLO DIÉGUEZ E VÁZQUEZ GÓMEZ 1994: 34-35; VÁZQUEZ GÓMEZ 1996: 411-461, CASTRO VIGO et al. 2003: 225-226) outras serán reconstruídas, reformadas e reformuladas (BELLO DIÉGUEZ 1991: 79-80; TOMÁS BOTELLA 200og) e tamén emerxerán outras de nova planta, como é o caso das construcións de Franxa 39 (DOVAL GALÁN 2000a; 200ob) ou Riego de Agua 40 (GONZÁLEZ FERNÁNDEZ $2000 b)$. Este proceso de reformulación urbana é visible ao longo de todo o entramado brigantino, e amosa un profundo cambio na estrutura interna e na orientación económica, produtiva e social do asentamento.

4 Considerado tamén, non obstante, como un posible déficit de información arqueolóxica. 


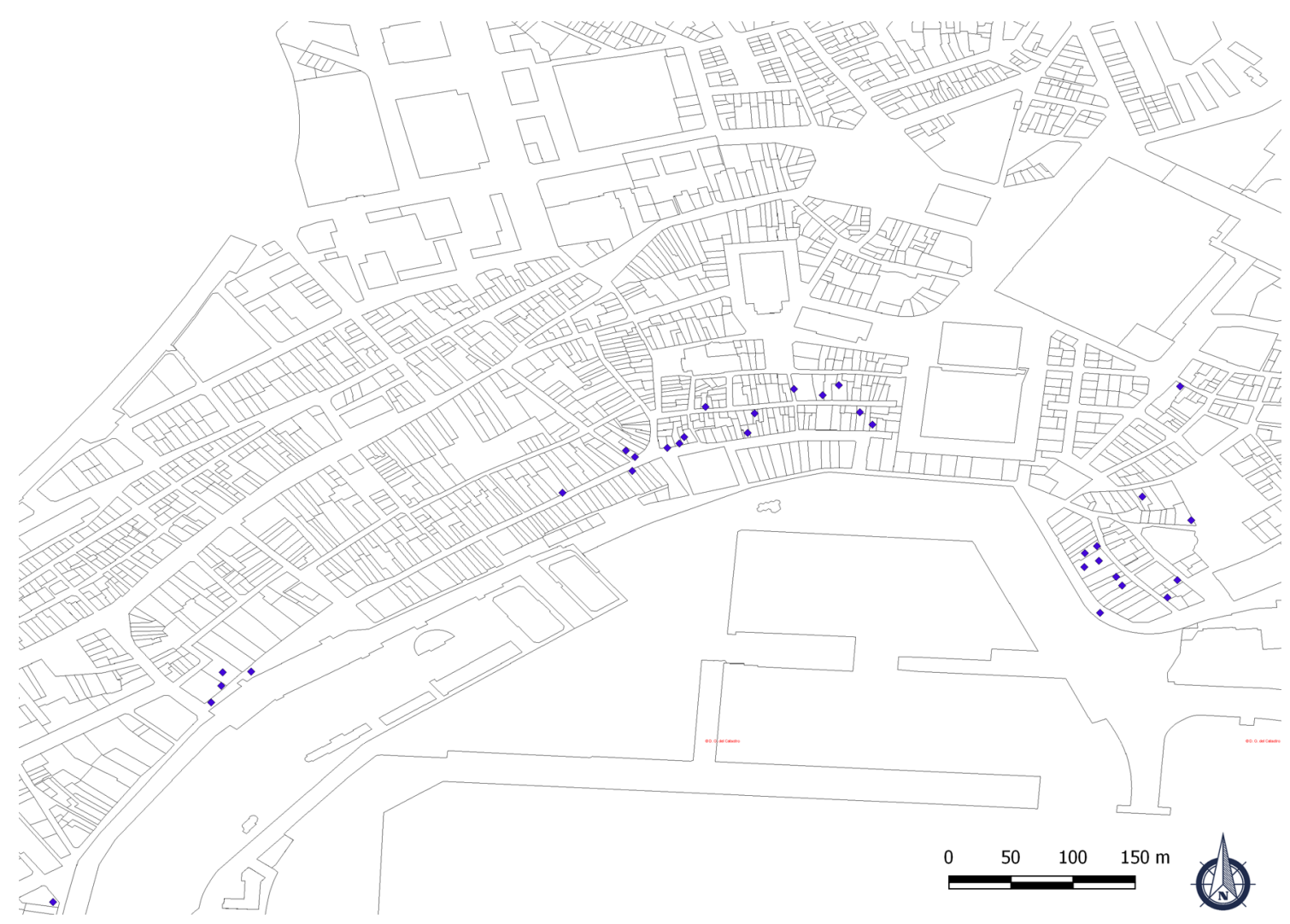

Figura 15. Niveis de ocupación con cronoloxías baixoimperiais (III-IV d.C.).

En definitiva, a pesar deste posible período de abandono, case todo o espazo ocupado en época altoimperial semella estar en uso durante os s. III-IV d.C., aínda que con certos matices. Se ben a zona de ocupación non se reduce, si que semella existir unha menor densidade de poboación. Se realizamos unha rápida comparativa cuantitativa entre niveis de ocupación de cronoloxías altoimperiais e baixoimperiais (sendo conscientes das problemáticas que isto implica), analizando unicamente aqueles espazos de posible uso habitacional e obviando outros niveis de uso (como pode ser a necrópole), contamos un total 23 altoimperiais por 17 baixoimperiais, unha cifra inferior, pero significativa.

Por outra parte, o poboamento baixoimperial semella ter unha disposición máis irregular e discontinua. Isto é apreciable en determinadas áreas da Cidade Vella: de forma coetánea á intensa zona de ocupación das rúas Parrote e Tabernas durante os s. III-IV d.C., así como outros espazos con niveis baixoimperiais en Porta de Aires e Azcárraga (TOMÁS BOTELLA 1997, RAMIL GONZÁLEZ 2001) en zonas como a rúa Damas non existen niveis de ocupación para estas cronoloxías. Esta discontinuidade semella menos apreciable na zona da Pescadería, mais pode ser inferible a través das diversas reconstrucións e abandonos de estruturas anteriores, tal e como comentamos previamente, que nos pode indicar a ausencia dun patrón urbanístico definido.

No referido aos límites, toda a parte $\mathrm{N}$ da vila semella non cambiar demasiado. Si que atopamos cambios na zona da necrópole, que semella estenderse máis aló dos límites da anterior, aínda que o asento da necrópole baixoimperial sobre a altoimperial puido facer desaparecer algúns restos arqueolóxicos. Este espazo de enterramento parece ocupar 
agora zonas anteriormente habitadas, como vemos en Riego de Agua 56 e 60 (BELLO DIÉGUEZ e VÁZQUEZ GÓMEZ 1994: 35; PENA BASSO 2008a), ou na destrución da posible construción da rúa Galera no 9 (VÁZQUEZ COLLAZO 2002a). Esta redución dun pequeno sector da zona anteriormente habitada pódenos indicar a lixeira caida poboacional xa indicada anteriormente. No referido ao limite $\mathrm{W}$ da necrópole, este semella idéntico ao altoimperial, non superando os n⿳0 40-50 da rúa Real, sen evidencias de ocupación baixoimperial de ningún tipo.

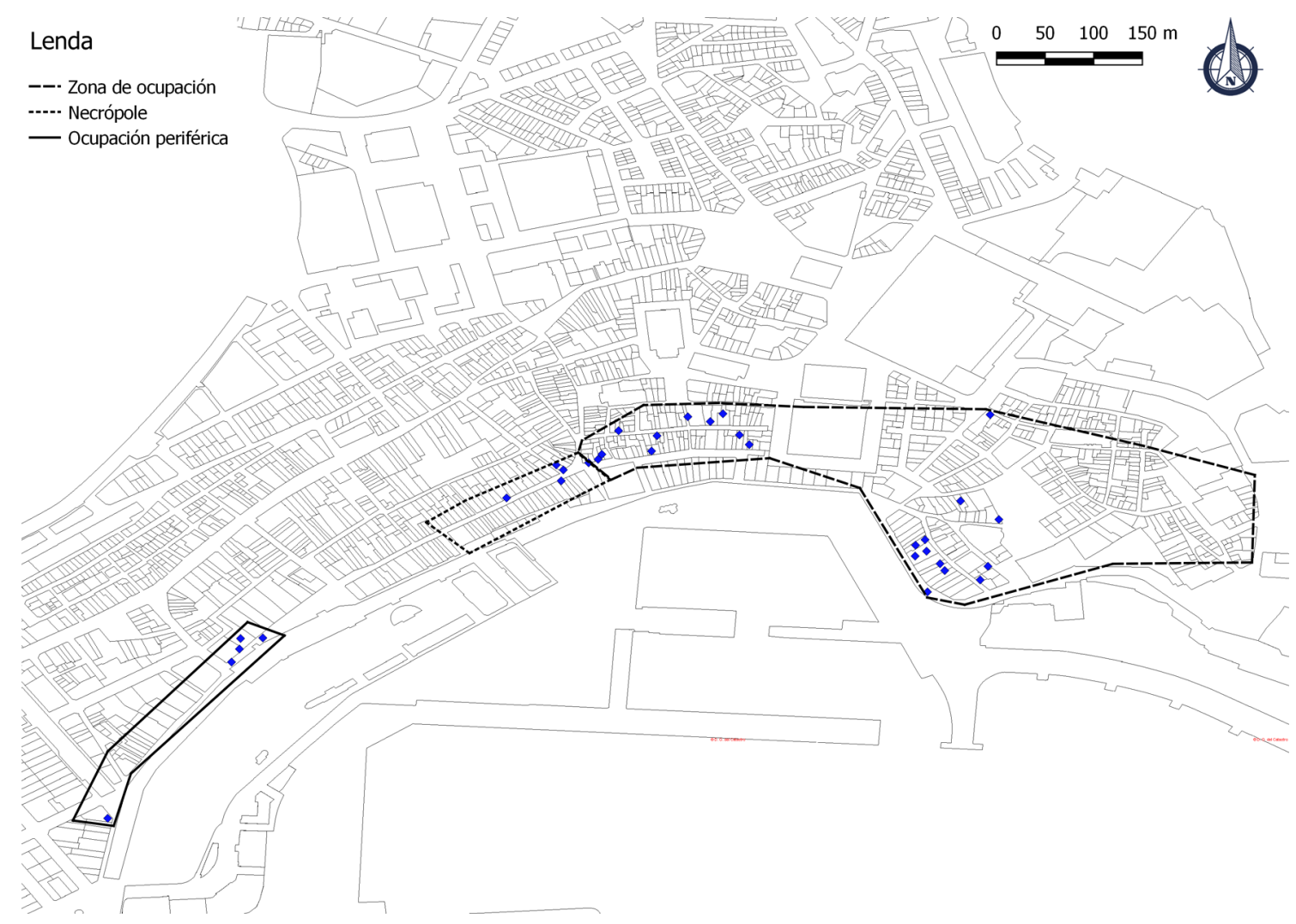

Figura 16. Brigantium en época baixoimperial (III-IV d.C.).

\section{CONTEXTOS E INTERPRETACIÓNS: COMO COMPRENDER A EVOLUCIÓN URBANA DE BRIGANTIUM}

O apartado anterior tiña como obxectivo analizar a evolución do entramado de Brigantium, os cambios na súa evolución ou os seus límites. Consideramos oportuno que estas propostas sexan acompañadas dunha interpretación histórica que nos axude a comprender esta evolución.

En primeiro lugar, e sen pretender plantear un debate sobre os inicios de Brigantium (cuestión que necesita unha revisión urxente), podemos atopar certo consenso no "despegue construtivo" desta vila portuaria en torno á época Flavia (GONZÁLEZ GARCÍA 2003: 259; LÓPEZ PÉREZ 2004; 2010: 98). Os estudos da terra sigillata atopada na Coruña realizados por López Pérez (LÓPEZ PÉREZ 2004; 2012) ou esta mesma revisión arqueolóxica amosan unha forte planificación construtiva dirixida e definida en época 
Flavia, que crearía un asentamento de nova planta fortemente estruturada pola administración imperial. Estas cronoloxías tamén semellan ser coherentes co rexistro arqueolóxico documentado para os inicios da Torre de Hércules ${ }^{5}$ (LÓPEZ PÉREZ 2004: 65-67; BELLO DIÉGUEZ 2008: 60-64; LÓPEZ PÉREZ 2012: 102-103), amósandonos, a nivel xeral, unha gran cantidade de tempo, esforzo e capital invertidos por Roma na península coruñesa nun período de tempo relativamente breve.

Así mesmo, a nivel epigráfico situámonos nun contexto cultural eminentemente formal, cuns 10 epígrafes que presentan características alleas a calquera influenza indíxena (NAVEIRO LÓPEZ 1988: 38; PÉREZ 2002: 121-122), con advocacións realizadas a deidades romanas, e unha antroponimia exclusivamente latina, que tamén evidencia a existencia de libertos imperiais. Ademais, a aparición de polo menos unha ara que nos menciona a presenza dun esxactor (TOMÁS BOTELLA 2004b, RODRÍGUEZ COLMENERO 2005) implicaría a existencia dunha statio do portorium, unha cuestión xa proposta con anterioridade (BALIL 1980: 167-173; VÁZQUEZ GÓMEZ 1991: 39; NAVEIRO LÓPEZ 1994: 58; GONZÁLEZ GARCÍA e BRAÑAS, 1995: 274) que agora xa semella confirmada, e que incide aínda máis no carácter administrativo do enclave.

Resulta chamativo, non obstante, que toda esta parafernalia imperial coexista cunha escaseza de material indicativo de comercio para estas épocas. É certo que documentamos fragmentos de material anfórico, así como múltiples tipos de cerámicas de importación, pero nunhas cantidades que semellan ter unha función de abastecemento do propio núcleo, sen chegar aos límites que poderiamos agardar para un teórico porto comercial. De feito, se deixamos a un lado á cerámica de luxo, que semella ser consumida dentro da propia cidade, a comparativa cos abondosos achados de material de importación atopados en Vigo (MORAIS e CARRERAS 2004: 103; LÓPEZ PÉREZ 2010: 102-103; FERNÁNDEZ FERNÁNDEZ 2016: 15-29) ou incluso Iria Flavia (LÓPEZ PÉREZ et al. 1999; PÉREZ LOSADA 2002: 108, 135) son bastante reveladoras se o relacionamos coas coleccións brigantinas, sobre todo se temos en conta a gran cantidade de intervencións realizadas. Estes dous aglomerados secundarios semellan ter unha entidade menor, tanto a nivel material como de infraestruturas, e tampouco amosan unha inversión de capital imperial comparable ao existente en Brigantium, porén, semellan ter unha intensidade comercial igual ou maior. Así mesmo, tampouco se constata a existencia de estrutura con funcionalidade produtiva que nos permita inferir a existencia dunha orientación de Brigantium cara o comercio ou a produción.

Todos estes datos lévannos a comprender o Brigantium altoimperial non como un espazo con funcións comerciais nin produtivas, senón administrativas, sendo este un espazo de tránsito e recalada necesario para a navegación e para a distribución de distintas mercadorías a través de diferentes rutas de transporte. Esta premisa, xa proposta nalgunha ocasión (PÉREZ LOSADA 2002, 135), semella ser a máis axeitada atendendo aos datos arqueolóxicos. A comprensión de Brigantium como espazo de tránsito non implica unicamente a súa relación coas vías de comunicación marítimas, senón tamén

5 Sen descartar unha ocupación de este espazo anterior, aínda que non estivera relacionado coa construción do faro (FERNÁNDEZ NIETO 2003, 43-64; RODRÍGUEZ COLMENERO e FERRER 2014). 
coas terrestres. Se ben non existe un claro consenso respecto á súa posición no entramado viario do Itinerario de Antonino (VÁZQUEZ GÓMEZ 1991; FRANCO 2000; PÉREZ LOSADA 2002: 117-119), persoalmente considero que resulta obvio que debeu formar parte da rede viaria romana, pois carece de lóxica considerar que o porto comercial de maior entidade do convento lucense non fose un punto capital para enlazar coa rede viaria. A súa localización semella ser imprescindible para o abastecemento de Ciadella e Lucus (PÉREZ LOSADA 2002: 136-137), dous emprazamentos de gran relevancia que semellan ter certa afinidade con Brigantium ${ }^{6}$. Outro elemento que tamén semella incidir na importancia da comunicación terrestre é a existencia de bastantes fragmentos terra sigillata importada dos talleres de Tritium (VÁZQUEZ GÓMEZ 1993-1994).

O desenvolvemento e auxe da Brigantium altoimperial semella acontecer ao longo do s. II d.C., mais dende os primeiros anos do III d.C. a súa ocupación semella decaer, tal e como se planteou nas páxinas anteriores. A nivel arqueolóxico resulta imposible definir os motivos desta desocupación parcial do núcleo brigantino, pero quizais poidamos recurrir a Orosio para poder comprender este auxe e caída da vila brigantina.

O teólogo bracarense menciona especificamente a relación entre o faro de Brigantium e as campañas militares realizadas en Britannia (OROSIO, I, 2, 70-72), dando a entender esta relación entre ambas prazas como algo intrínseco e natural. Tendo en conta a relación inalienable entre o faro e da vila de Brigantium, resulta bastante lóxico propoñer unha posible relación entre a evolución altoimperial da vila romana coruñesa e as campañas militares británicas. Esta idea, que xa foi planteada anteriormente (BELLO DIÉGUEZ 2008: 61-63), non só cadra case á perfección tanto coas funcións como coas cronoloxías de Brigantium, senón que pode indicarnos un posible camiño para comprender as súas fases históricas. Dada a súa situación xeográfica, Brigantium semella ser un punto loxístico esencial para suministrar múltiples produtos ás tropas acuarteladas en Britania (BELLO DIÉGUEZ 2008: 62). Estas campañas desenvolveríanse, principalmente, ao longo dos s. I e II d.C., cesando tras a morte de Septimio Severo no 211 d.C., o último emperador interesado na loita máis aló do muro de Adriano77 (MENÉNDEZ ARGUín 2016).

Esta relación coas campañas militares británicas non só poría de manifesto a relación de dependencia brigantina respecto á administración imperial, senón que ademais amosaría un dos posibles factores na súa decadencia. O intensa diminución das campañas militares en Britania (e por ende, da necesidade de abastecelas) nos primeiros anos do século III d.C. son datas nas que podemos situar o "abandono" de boa parte das construcións altoimperiais, un dato que quizais sexa relevante para a comprensión deste decrecemento na poboación. Resulta lóxico que, dentro dunha vila cunha forte dependencia imperial, a diminución ou o cese dunha das súas rutas principais implique unha forte influenza na súa organización interna, sendo o abandono parcial do encrave unha consecuencia lóxica e razoable. Ademais, sen centrarse en Britania, o certo é bastantes rutas atlánticas de abastecemento comezan a decaer en importancia, ao centrarse Roma

6 A relación Brigantium-Lucus, habitualmente mencionada, é unha cuestión que merecería unha publicación propia dende múltiples perspectivas, pois a súa presenza material e as súas dinámicas sociais semellan amosar alguunhas liñas converxentes que sen dúbida merecen un estudo particular.

7 De feito, Severo morrerá en Eburacum (York), tras múltiples conflitos bélicos coas tribus britanas. 
noutros focos de actuación como poden ser as campañas de Oriente (GARRIDO GONZÁLEZ 1990). Non obstante, debemos de ser conscientes de que esta posible relación Britannia-Brigantiun non se trata do único factor relevante para analizar a evolución do asentamento, e en todo caso debemos de interpretar este feito como unha evidencia máis que nos indica a forte dependencia do asentamento respecto ás decisións da administración imperial. Así mesmo, tampouco debemos esquecer outros aspectos como as propias dinámicas internas da cidade ou do seu contexto, pois este decaemento poboacional acontece en pleno inicio dun proceso de reorganización social a nivel xeral, que redefiniría todo o poboamento da Gallaecia (SÁNCHEZ PARDO 2008: 412).

Así mesmo, como planteamos anteriormente, non podemos falar dun abandono total para estas cronoloxías. Algunhas estruturas seguen en uso durante estes momentos, como é o caso das construcións dos Cantóns e posiblemente Sánchez Bregua 2-3 ou Tabernas 10-12 (VÁZQUEZ COLLAZO 1998a; 1999a; TOMÁS BOTELLA 2008c; MARTÍNEZ 2009, LÓPEZ PÉREZ E TOMÁS BOTELLA 2010)ํ, e outras estruturas altoimperiais poderían estender a súa fase de ocupación ata algúnhas décadas do s. III d.C. (GONZÁLEZ 200ob, TOMÁS BOTELLA 2001d). Esta breve fase de abandono resulta moi complicada de situar a nivel cronolóxico (unha aproximación moi aventurada podería situalo entre o 220 e o 260 d.C.), pero é apreciable a través de múltiples factores, como a ausencia de continuidade na inmensa maioría de estruturas altoimperiais, algunhas reconstruídas anos máis tarde. Esta reestruturación implicaría, por si mesma, unha reformulación da orientación funcional do propio asentamento. Anteriormente un encrave eminentemente imperial, agora semella ser parte dun proceso xeral no que a fragmentación política é maior, aparecendo múltiples células económicas, políticas e produtivas, que poden ser visibles a través de elementos como as villae (PÉREZ LOSADA 2002: 51-59; SÁNCHEZ PARDO 2008: 401-466). Este tipo de xacementos, moi habituais nalgúns espazos costeiros do Golfo Ártabro (LUENGO MARTÍNEZ 1962; PÉREZ LOSADA 1997), semellan estar presentes en Brigantium en polo menos dous casos.

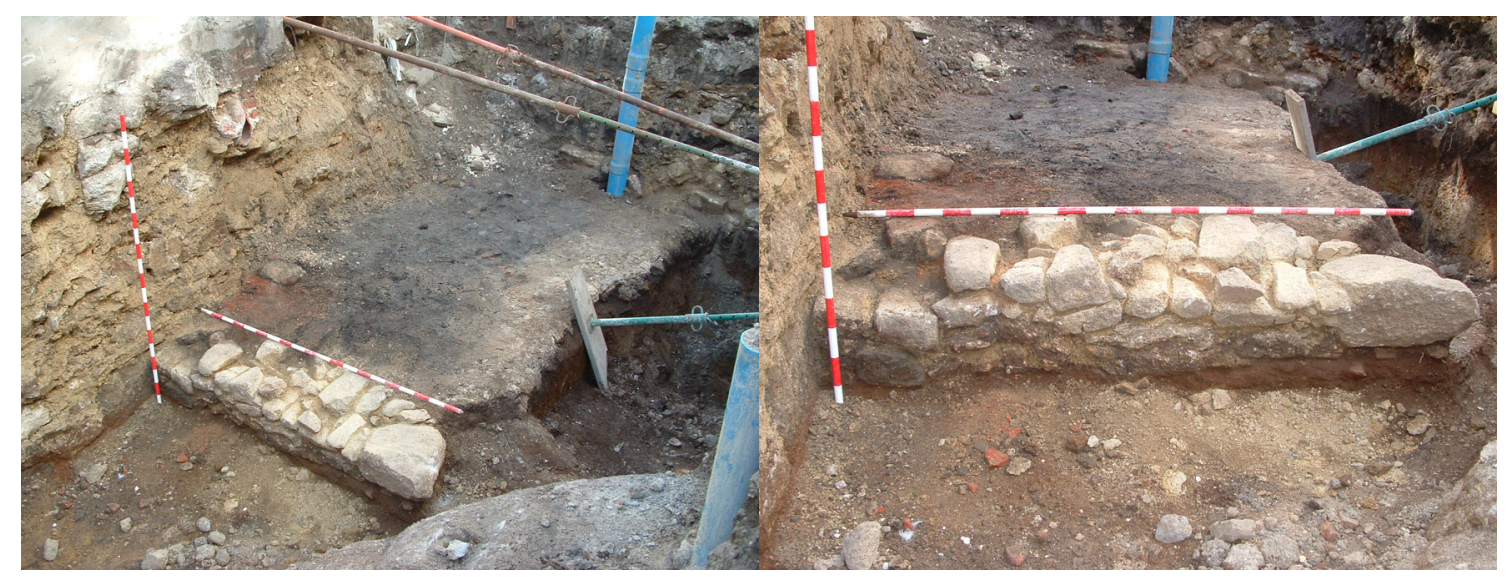

Figura 17. Detalle da escavación en Parrote 14 (TOMÁS BOTELLA 2007b).

8 Non obstante, tal e como dixemos, as edificacións dos Cantóns e Sánchez Bregua 2-3 semellan estar nunha zona periférica, e pode que non formen parte das mesmas dinámicas sociais do núcleo "urbano" de Brigantium, podendo estar en relación con determinadas funcións asociadas ao camiño de acceso. 
Por outra parte, aínda que os niveis arqueolóxicos e os materiais de importación baixoimperiais semellan amosar un lixeiro decaemento cuantitativo respecto a épocas altoimperiais (LÓPEZ PÉREZ 2004: 72; 2012: 102-103), o certo é que a finais do s. IIIcomezos do s. IV d.C. observamos unha clara reactivación da vila. Non existe, como se ten proposto, un retraemento poboacional á Cidade Vella (LÓPEZ PÉREZ E MUÍÑO MANEIRO 2011: 133), pois existen múltiples zonas ocupadas dende mediados-finais do s. III ao longo do emprazamento, aínda que é certo que existen construcións moi potentes na súa zona Sur, que poden insinuar unha posible renovación ou fortalecemento deste espazo debido á influenza da actividade portuaria. En todo caso, se ben existe unha reformulación e reconstrución do entramado poboacional, non semella atender a un plan urbanístico xeral, ou polo menos, non a un semellante ás directrices anteriores marcadas pola vella cidade altoimperial. As reocupacións e rehabilitacións dos espazos antigos semellan ser aleatorias, polo menos a nivel arqueolóxico, ocupando algúns espazos vellos ao mesmo tempo que outras zonas colindantes permanecen en desuso.

Os motivos deste proceso resultan difíciles de inferir, mais atopámonos nun momento de fragmentación política e social, dentro dun proceso de reconfiguración da ordenación territorial a nivel xeral no que as formas de ocupación e a xerarquización dos asentamentos cambian por completo (SÁNCHEZ PARDO 2008: 408-425). Esta fragmentación política, a redución do papel imperial e a aparición de novas formas de explotación e de organización socioeconómica marcarían un novo proceso que continuaría durante os seguintes séculos. Estamos ante unha nova vida para Brigantium, máis afastada da administración imperial e máis relacionada coa aparición de pequenos espazos produtivos independentes, cunha maior dependencia da capacidade de axencia das elites locais e dentro dunha estrutura social moito máis fragmentada. Este último proceso parece bastante visible noutras localizacións, como pode ser o caso de Vigo (PÉREZ LOSADA 2002: 261-266).

\section{Conclusións}

En definitiva, estas dúas décadas de actividade arqueolóxica ofrecen información clave para seguir avanzando no coñecemento da vella Brigantium. Esta exposición dos seus avances non serve unicamente para dar a coñecer a información ou para realizar unha nova interpretación sobre algunhas características da súa ocupación, senón que tamén pode axudar a devolver á actualidade científica un tema un tanto esquecido nos últimos anos.

Estas novas intervencións arqueolóxicas posibilitan un coñecemento máis profundo do entramado brigantino e dalgunhas das súas principais características. En primeiro lugar debemos destacar a existencia de dúas etapas claramente diferenciadas na vida de Brigantium para as cronoloxías que nos ocupan. A primeira, situable en torno ao 60-70 d.C., amosa unha vila que semella ser un encrave portuario, con condicións privilexiadas para a navegación marítima e cun plan urbanístico bastante ben estruturado por parte da administración imperial, pero cunhas evidencias de intercambio moi escasas, que 
abranguen pouco máis das necesidades do poboado. Estes datos, xunto cun contexto cultural "formal" e coas múltiples evidencias de traballadores da administración romana, semellan levarnos a unhas funcionalidades eminentemente administrativas, unha vila que sería un espazo administrativo con funcións loxísticas para o tránsito e recalada de diferentes rutas comerciais, tanto marítimas como terrestres. Todo o seu espazo construtivo semella ser realizado nun período temporal relativamente escaso, cunha gran densidade de poboación e cunhas dimensións (podemos calcular unhas 6-8 ha de espazo habitacional, sen contar a zona da necrópole) que non serían superadas ata centos de anos despois.

Este momento de auxe duraría ata os primeiros anos do s. III d.C., cando podemos apreciar unha drástica caída poboacional, aparentemente apreciable polo abandono da gran maioría das construcións altoimperiais. Esta caída pode poñerse en relación coa súa probable dependencia da administración imperial e das súas rutas de comunicación. Nesta liña, resulta interesante a relación xa apuntada por Orosio entre Brigantium e o abastecemento de Britania, coincidindo sorprendentemente no tempo o cese de campañas militares na illa cos primeiros momentos de abandono da urbe coruñesa. Este factor, que pode axudar a comprender a forte dependencia da administración imperial que tiña Brigantium, non debe de ser tomado como a única causa, pois atopámonos en pleno inicio dun proceso máis amplo de reorganización das formas de ocupación e na xerarquización do poboamento dentro da propia Gallaecia (SÁNCHEZ PARDO 2008: 408-425).

Esta acusada diminución da poboación non se prolongaría demasiado no tempo. A partires do último terzo do s. III, semella existir un forte rexurdimento do núcleo central, que reformula, reconstrúe ou edifica sobre as construcións imperiais anteriores, moitas delas xa abandonadas. Estamos ante unha nova fase que non chega aos límites da densidade de poboación altoimperial, tal e como podemos inferir do avance da zona da necrópole cara ao E ou da desocupación de determinadas zonas anteriormente ocupadas. A aparente ausencia dunha planificación urbanística xeral (ou, en todo caso, o abandono da organización urbana previa) e a aparición de posibles villae lévanos a pensar nunha reconstrución baseada en novos modelos, coa aparición de novas formas de explotación e cunha fragmentación política máis acusada, na liña destes procesos de reorganización social e política xa comentados con anterioridade. Esta nova etapa, que se estendería durante os primeiros séculos do medievo, semella ser relativamente intensa na península coruñesa, e ofrece un gran reto para futuras investigacións.

\section{Bibliografía}

ALBERTOS FIGUEROA, B. 2010. Escavación arqueolóxica en área. Real, 24 (A Coruña). Informe valorativo. Informe valorativo inédito.

ALBERTOS FIGUEROA, B. 2015. Memoria técnica do control arqueolóxico do proxecto de mellora de mobilidade peonil na rúa Capitán Troncoso con Xeneral Alesón (A Coruña). Memoria técnica inédita.

BALIL ILLANA, A. 1977. "Reflejos galaicos de la familia Cesaris”. En J. Maluquer de Motes y Nicolau (ed.). Actas del coloquio internacional sobre el bimilenario de Lugo. Lugo, pp. 123-129. 
BALIL ILLANA, A. 1980. “¿Restos de un puerto romano en la Coruña?”, Brigantium, 1, 167-173.

BELLO DIÉGUEZ, J.M. 1991. "La Coruña Romana”. En J.M. Bello Diéguez e A. Vigo Trasancos. Ciudad y Torre. Roma y la ilustración en La Coruña. A Coruña, pp- 73-105.

BELLO DIÉGUEZ, J.M. 2008. "Brigantium y su faro. Contextos arqueológicos en la ciudad de A Coruña”. Brigantium, 20, 41-67.

BELLO DIÉGUEZ, J.M. e VÁZQUEZ GÓMEZ, X.L. 1994. “Arqueoloxía urbana na Coruña”. En FERNÁNDEZ MALDE, A. (ed.). Patrimonio e Cidade. A Coruña, Cidade Vella e Pescadería. A Coruña, pp. 31-36.

BLANCO SANMARTÍN, Ma P. 1999. Memoria técnica do control de obra a Rúa Galera $n^{o} 3$ de A Coruña. Memoria técnica inédita.

BLANCO SANMARTÍN, Ma P. 2002. Sondaxes arqueolóxicas no $n^{o} 3$ da Rúa de Santa María, A Coruña. Memoria. Memoria técnica inédita.

BONILLA RODRÍGUEZ, A. 2006. Sondeos arqueológicos valorativos en Calle Real $N^{o} 77$ (A Coruña). Informe memoria. Informe-memoria inédito.

CASTRO PAREDES, I. 2002. Sondaxes valorativas previas á reconstrución dun edificio sito en Rúa Amargura, 7. Informe valorativo inédito.

CASTRO PAREDES, I.; ÍNSUA LIÑARES, Mª J.; LÓPEZ PÉREZ, Ma C. 2003. “Aportaciones a la arqueología urbana de A Coruña: la Casa Martelo a través de sus materiales”. Brigantium, 14, pp. 225-243.

CASTRO VIGO, E. 2009. Informe valorativo: R/ Rego de Auga, 38; R/ Franxa, 43 (A Coruña). Informe valorativo inédito.

CASTRO VIGO, E. 2010a. Informe incidencias: R/ Rego de Agua 38; R/ Franxa 43 (A Coruña). Informe inédito.

CASTRO VIGO, E. 2010b. Informe Memoria. R/ Rego de Auga 29 (A Coruña). Informe-memoria inédito.

CORDEIRO MAÑÓN, L. 2005. Escavación arqueolóxica na casona da Rúa Príncipe, 8 (A Coruña). Memoria técnica inédita.

DOVAL GALÁN, J.F. 2000a. Informe valorativo da intervención arqueolóxica no solar $n^{o} 39$ da Rúa da Franxa (A Coruña). Informe valorativo inédito.

DOVAL GALÁN, J.F. 200ob. Memoria técnica da intervención arqueolóxica no solar $N^{o} 39$ da Rúa da Franxa (A Coruña). Memoria técnica inédita.

ELGUERO CÓRDOBA, L. 2000. Control arqueológico en la R/ Varela Silvari $N^{o} 37$. A Coruña. Informe/Memoria. Informe-memoria inédito.

FERNÁNDEZ ABELLA, D. 2013. "Proxecto de sondaxes arqueolóxicas valorativas no no 17 da rúa Santo Agostiño da cidade da Coruña”. En M. P. Fernández Campos (coord.). Actuacións arqueolóxicas (ano 2009). Santiago de Compostela, pp. 133-135.

FERNÁNDEZ FERNÁNDEZ, A. 2016. "25 anos de arqueoloxía de urxencia. O descubrimento do Vigo romano”. En A. Fernández Fernandez; P. Barciela Garrido (eds.). Mil anos de comercio en Vigo. Vigo.

FERNÁNDEZ MALDE, A. 2017. Prospección con xeorradar e sondaxes valorativas na contorna do campo de fútbol de Eirís. Informe valorativo inédito.

FERNÁNDEZ RODRÍGUEZ, O. 2000a. Informe valorativo sondaxe arqueolóxica. Reforma e ampliación de edificio de vivendas. Rúa Damas, 6. A Coruña. Informe valorativo inédito.

FERNÁNDEZ RODRÍGUEZ, O. 200ob. Informe valorativo intervención arqueolóxica (sondaxes valorativas). Reforma e ampliación de edificio de vivendas. Rúa Damas, 6. A Coruña. Informe valorativo inédito.

FERNÁNDEZ NIETO, F. J. 2003. "El trofeo de Augusto en Occidente. La evocación de Alejandro y la ocupación de la Hispania extrema”. En M. P. García Ruíz (coord.). Urbs aeterna: actas y colaboraciones del Coloquio Internacional "Roma entre la literatura y la historia". Madrid, pp. 43-64.

FERRER CRUZ, X. 2007. Sondaxes arqueolóxicas valorativas na rúa Porta de Aires $n^{\circ} 7$ (A Coruña). Informe de valoración. Informe valorativo inédito. 
FERRER CRUZ, X. 2010. Control arqueolóxico de remoción de terras para un oco de ascensor no número 19 da rúa Barreira ( $A$ Coruña). Informe-memoria inédito.

FRANCO MASIDE, R. 2000. "Rutas naturais e vías romanas na provincia de A Coruña”. Gallaecia, 19, 143-170.

GARRIDO GONZÁLEZ, E. 1990. "Siria y el enfrentamiento romano-sasánida en el siglo IV d.c. Polis, 2, $143-156$.

GONZÁLEZ FERNÁNDEZ, A. 2000a. Control arqueológico en Calle Barrera 21. A Coruña. Memoria. Informe-memoria inédito.

GONZÁLEZ FERNÁNDEZ, A. 200ob. Sondeo arqueológico: proyecto básico y ejecución de reestructuración de edificio en el $n^{\circ} 40$ de la C/ Riego de Agua. A Coruña (A Coruña). Informe valorativo. Informe valorativo inédito.

GONZÁLEZ GARCÍA, F.J. 2003. Os ártabros. Estudo xeográfico e etnohistórico. Ourense.

GONZÁLEZ GARCÍA, F.J. e BRAÑAS ABAD, R. 1995. Galicia romana. Historia de Galicia, Tomo II. Oleiros.

GONZÁLEZ VILLAESCUSA, R. 2001. El mundo funerario romano en el País Valenciano. Monumentos funerarios y sepulturas entre los siglos I a.c. - VII d.C. Madrid-Alicante.

GRANDAL D’ANGLADE, A.; SERRULLA RECH, F.; TOMÁS BOTELLA, V.; PÉREZ RAMA, M.; GÓMEZ, M.; RAMIL GONZÁLEZ, E. 2015. "Vida y muerte de dos mujeres de Brigantium (NW de Iberia) mediante isótopos estables y antropología forense”. Cadernos Laboratorio Xeolóxico de Laxe, 38, 45-66.

ÍNSUA LIÑARES, Ma J. 2001. Sondaxes Arqueolóxicas Valorativas do Proxecto de reedificación dun edificio na rúa Sinagoga, 1. Informe valorativo inédito.

LÓPEZ ALONSO, J. 2003. Tabernas $N^{o} 4$ (A Coruña). Informe valorativo. Informe valorativo inédito. LÓPEZ ALONSO, J. 2005. C/ Real $N^{o}$ 56. A Coruña. Informe. Informe valorativo inédito.

LÓPEZ CORDEIRO, MaM. 2005. Sondeos arqueológicos en el solar $n^{o} 4$ de la Rúa San Carlos (A Coruña). Informe valorativo/memoria técnica. Informe-memoria inédito.

LÓPEZ PÉREZ, Ma C. 2004. El comercio de terra sigillata en la provincia de A Coruña. Brigantium, 16, A Coruña.

LÓPEZ PÉREZ, Ma C. 2008. "Brigantium como centro de consumo de Terra sigillata”. Férvedes, 5, 397-403.

LÓPEZ PÉREZ, Ma C. 2010. "Reflexiones sobre la época Flavia en Brigantium a partir de los datos proporcionados por la Terra Sigillata. CUPAUAM, 36, 95-106.

LÓPEZ PÉREZ, Ma C.; ÁLVAREZ GONZÁLEZ, Y.; LÓPEZ GONZÁLEZ, L. 1999. "Evidencias materiales de la actividad comercial romana en Iria Flavia (Padrón, A Coruña): las sigillatas”. Gallaecia, 18, 239-264.

LÓPEZ PÉREZ, Ma C. e MUÍÑO MANEIRO, X.A. 2011. "La terra sigillata en A Coruña: primeros resultados de la intervención practicada en el no 8 de la calle Damas". Gallaecia, 30, 127-134.

LÓPEZ PÉREZ, Ma C. e TOMÁS BOTELLA, V. 2010. "La vajilla fina de mesa de época romana en los solares no 10-12 de la calle Tabernas (A Coruña). Gallaecia, 29, 173-190.

LUENGO MARTÍNEZ, J.M. 1953. Las excavaciones de la necrópolis romana de La Coruña. Publicaciones del Seminario de Arqueología y Numismática Aragonesa, v. 1661, 415-427.

LUENGO MARTÍNEZ, J.M. 1962. "Las escavaciones de la villa romana de Centroña-Puentedeume (La Coruña)". Cuadernos de estudios gallegos, T. $17 \mathrm{n}^{0}$ 51, 5-19.

MARTÍNEZ CASAL, J.R. 2009. R/ Sánchez Bregua, 2 (A Coruña). Escavación arqueolóxica. Informe valorativo. Informe valorativo inédito.

MÉNDEZ FERNÁNDEZ, F. 2005. Excavación arqueológica en área en el inmueble de la calle Riego de Agua 3-5. A Coruña. Informe valorativo de los trabajos. Informe valorativo inédito.

MÉNDEZ FERNÁNDEZ, F. 2014. Excavación en el Castro de Elviña: Informes valorativos de los trabajos de excavación arqueológica. Informe valorativo inédito.

MENÉNDEZ ARGUín, A.R. 2016. “Las reformas militares de Septimio Severo”. Desperta Ferro, 35, 24-29. 
MORAIS, R. e CARRERAS MONFORT, C. 2004. "Geografia del consum”. En C. Carreras Monfort; X. Aquilué (eds.). Culip VIII i les anfores Haltern 7o, Monografias 5. Girona, pp. 93-116.

MUÍNONO MANEIRO, X.A. 2001a. Informe preliminar. Intervención arqueolóxica (sondaxes arqueolóxicas): Cortaduría, 15 (A Coruña). Informe valorativo inédito.

MUÍÑO MANEIRO, X.A. 2001b. Memoria técnica. Intervención arqueolóxica (sondaxes arqueolóxicas): Cortaduría, 15 (A Coruña). Memoria técnica inédita.

MUÍÑO MANEIRO, X.A. 2003a. Informe valorativo. Interevnción arqueolóxica (sondaxes arqueolóxicas): Damas 8 (A Coruña). Informe valorativo inédito.

MUÍÑO MANEIRO, X.A. 2003b. Informe valorativo. Interevnción arqueolóxica (escavación en área): Damas 8 (A Coruña). Informe valorativo inédito.

MUÍÑO MANEIRO, X.A. 2005a. Informe-memoria: Cortaduría, 5+7 (A Coruña). Informe-memoria inédito.

MUÍÑO MANEIRO, X.A. 2005b. Informe valorativo: Sondaxes arqueolóxicas. Franxa, 36 (A Coruña). Informe valorativo inédito.

MUÍÑ MANEIRO, X.A. 2005c. Memoria técnica: Sondaxes arqueolóxicas. Franxa, 36 (A Coruña). Memoria técnica inédita.

MUÍÑO MANEIRO, X.A. 2006. Intervención arqueolóxica en Riego de Agua, 56. Informe valorativo inédito.

MUÍÑO MANEIRO, X.A. 2008a. Informe valorativo: Parrote 16 (A Coruña). Informe valorativo inédito.

MUÍÑO MANEIRO, X.A. 2008b. Informe valorativo: sondaxes arqueolóxicas. $R /$ Damas $N^{o} 3$ (A Coruña). Informe valorativo inédito.

MUÍÑO MANEIRO, X.A. 2008c. R/ Santiago 17 (A Coruña). Sondaxes arqueolóxicas. Informe-memoria. Informe-memoria inédito.

MUÍÑO MANEIRO, X.A. 2008d. Informe memoria R/ Santa Catalina no 25, 27, 29, 31 e 33 (A Coru$\tilde{n} a)$. Informe-memoria inédito.

MUÍÑO MANEIRO, X.A. 2009a. Informe-memoria R/ Amargura, 17 (A Coruña). Apertura de zanxa para acometida de augas. Actuación: control arqueolóxico. Informe-memoria inédito.

MUÍÑ MANEIRO, X. A. 2009b. Praza de España $n^{o} 13$ (A Coruña). Informe - memoria. Informememoria inédito.

NAVEIRO LÓPEZ, J.L. 1985. Informe preliminar sobre la excavación de urgencia de los restos romanos de la plaza de $M^{a}$ Pita (A Coruña). Informe valorativo inédito.

NAVEIRO LÓPEZ, J.L. 1988. "Arqueología urbana en Coruña y definición del asentamiento romano. Semata, 1, 35-62.

NAVEIRO LÓPEZ, J.L. 1991. El comercio antiguo en el NW peninsular. A Coruña.

NAVEIRO LÓPEZ, J.L. 1994. El Golfo Ártabro: arqueologia e historia del gran puerto de los Galaicos Lucenses. A Coruña.

NAVEIRO LÓPEZ, J.L. 2009. Sondaxes arqueolóxicas na rúa Príncipe 3. Cidade Vella - A Coruña. Informe valorativo e memoria final. Informe-memoria inédito.

PARGA CASTRO, A. 2001. Control arqueológico en las obras de rehabilitación y reforma de edificio de viviendas de planta baja, tres plantas altas y aprovechamiento bajo cubierta, sito en la Calle Torre $\mathrm{N}^{o}$ 2, La Coruña. Informe-memoria. Informe-memoria inédito.

PARGA CASTRO, A. 2002. Control arqueológico en las obras de construcción de un edificio destinado a Apartahotel de P.L. en la Calle San Andrés $N^{o} 111$ y 107, A Coruña. Informe-memoria. Informememoria inédito.

PELLICER MOR, J.L. 1994. "Roma conquista Britania: Las campañas militares". Historia 16, nº 224, 64-75.

PENA BASSO, S. 2002. Sondaxes arqueolóxicas valorativas na Rúa San Andrés, 5 (A Coruña). Informe valorativo inédito.

PENA BASSO, S. 2003. Sondaxes arqueolóxicas valorativas na Rúa Santiago, 19 (A Coruña). Memoria técnica. Memoria técnica inédita. 
PENA BASSO, S. 2007a. Sondaxes mecánicas valorativas na Rúa San Andrés, $n^{\circ}$ 115-117 (A Coruña). Informe valorativo. Informe valorativo inédito.

PENA BASSO, S. 2007b. Control arqueolóxico de remoción de terras na Rúa Santa Catalina, $N^{\circ} 24$ (A Coruña). Memoria técnica. Memoria técnica inédita.

PENA BASSO, S. 2008a. Escavación arqueolóxica en área na Rúa Riego de Agua, 56 (A Coruña). Informe valorativo. Informe valorativo inédito.

PENA BASSO, S. 2008b. Sondaxes arqueolóxicas valorativas na rúa Capitán Troncoso no 20 (A Coruña). Memoria técnica. Memoria técnica inédita.

PENA BASSO, S. 2008c. Sondaxes arqueolóxicas valorativas na rúa Porta de Aires $n^{\circ} 9$ - Travesía de Herrerías $n^{\circ} 2$ ( $A$ Coruña). Memoria técnica. Memoria técnica inédita.

PENA BASSO, S. 2009. Sondaxes arqueolóxicas valorativas na Avenida da Marina, $n^{o} 14$ ( A Coruña). Informe valorativo. Informe valorativo inédito.

PENA BASSO, S. 2010a. Sondaxes arqueolóxicas valorativas na rúa Porta de Aires $n^{\circ} 9$ - Travesía de Herrerías $n^{\circ}$ 2. Memoria técnica. Memoria técnica inédita.

PENA BASSO, S. 2010b. Sondaxes arqueolóxicas na Praza de María Pita $N^{o}$ 10. Memoria técnica. Memoria técnica inédita.

PENA BASSO, S. 2012. Control arqueolóxico na rúa Riego de Agua, 56 (A Coruña). Informe valorativo do estado do solar. Informe valorativo inédito.

PENA BASSO, S. 2013. "Sondaxes arqueolóxicas valorativas na Avenida da Mariña, no 14 (A Coruña). En M. P. Fernández Campos. (coord.). Actuacións arqueolóxicas (ano 2009). Santiago de Compostela, pp. 124-127.

PENA BASSO, S. 2015. Control e seguimento arqueolóxico de remoción de terras para instalación de distribución de Gas Natural no ámbito da zona Pepri de A Coruña. Ano 2015. Memoria técnica. Memoria técnica inédita.

PENA BASSO, S. 2017a. Control arqueolóxico de remoción de terras para RBTS na Rúa da Barrera, 10. Informe valorativo. Informe valorativo inédito.

PENA BASSO, S. 2017b. Control arqueolóxico de remoción de terras para catas por avarías na Rúa Santa Marta $n^{\circ} 5$ e Rúa Herrerías $n^{\circ} 30$. Informe valorativo inédito.

PENA BASSO, S. 2017c. Control arqueolóxico de remoción de terras para catas por avaría na Rúa da Franxa, 50. Informe valorativo. Informe valorativo inédito. Informe valorativo inédito.

PENA BASSO, S. 2017d. Control arqueolóxico de remoción de terras para cata por avaría na Avda. Da Marina (entre as rúas Agar e Luchana). Informe valorativo. Informe valorativo inédito.

PENA BASSO, S. 2017e. Control arqueolóxico de remoción de terras para cata por avaría na Rúa Orzán $N^{o}$ 149. Informe valorativo. Informe valorativo inédito.

PENA BASSO, S. 2017f. Control arqueolóxico de remoción de terras para cata por avaría na Rúa Orzán, 128. Informe valorativo. Pena Basso, $S$. Informe valorativo inédito.

PENA BASSO, S. 2017g. Control arqueolóxico de remoción de terras para cata por avaría na Avda. Puerta de Aires (CT General Alesón). Informe valorativo. Informe valorativo inédito.

PENA BASSO, S. 2017h. Control arqueolóxico de remoción de terras para catas por avaría na rúa San Andrés, 141. Informe valorativo. Informe valorativo inédito.

PENA BASSO, S. 2017i. Control arqueolóxico de remoción de terras para RBTS na estrecha de San Andrés 1-3. Informe valorativo. Informe valorativo inédito.

PENA BASSO, S. 2017l. Apertura de zanja para substitución de acometida de alcantarillado en la Calle San Andrés $n^{\circ} 160$ (A Coruña). Memoria de control y seguimiento arqueológico. Memoria técnica inédita.

PENA BASSO, S. e CASTRO PAREDES, I. 2017. Control e seguimento arqueolóxico do "Proyecto de mejora de pavimento en la calle Orillamar" ( C Coruña). Memoria Técnica. Memoria técnica inédita.

PEREIRA MENAUT, G. 1994. Corpus de inscricións romanas de Galicia. Vol I. Santiago de Compostela. PÉREZ LOSADA, F. 1995. “A romanización rural do golfo Ártabro e as mariñas coruñesas”. En J. M. Bello Diéguez e A. Vigo Trasancos. Ciudad y Torre. Roma y la ilustración en La Coruña. A Coruña, pp. 29-33. 
PÉREZ LOSADA, F. 1996. "Hacia una definición de los asentamientos rurales en la Callaecia: poblados (vici) y casas de campo (villae)”. En C. Fernández Ochoa (coord.). Los finisterres atlánticos en la Antigüedad. Época prerromana y romana. Madrid, pp. 189-200.

PÉREZ LOSADA, F. 1997. "Sobre a villa romana de Noville (Mugardos): síntese divulgativa e valoración patrimonial”. En V. Alonso Troncoso (coord.). Ferrolterra galaico-romana. Ferrol, pp. 85-135.

PÉREZ LOSADA, F. 2002. Entre a cidade e a aldea. Estudo arqueohistórico dos "aglomerados secundarios" romanos en Galicia. Brigantium, 13. A Coruña.

PRADO FERNÁNDEZ, O. 2002a. Informe valorativo das sondaxes arqueolóxicas na Rúa de San Carlos, $n^{\circ} 8$, A Coruña. Informe valorativo inédito.

PRADO FERNÁNDEZ, O. 2002b. Informe valorativo e memoria técnica do control arqueolóxico na rúa Barrera, $n^{\circ}$ 5, na Cidade da Coruña. Informe-memoria inédito.

PRADO FERNÁNDEZ, O. 2003a. Informe valorativo e memoria técnica das sondaxes arqueolóxicas na rúa Barrera, $n^{o} 32$, A Coruña. Concello da Coruña. Informe-memoria inédito.

PRADO FERNÁNDEZ, O. 2003b. Sondaxes arqueolóxicas na praza Ángeles $n^{\circ} 7$ - rúa Santiago $n^{\circ} 7$. A Coruña. Memoria técnica inédita.

PRADO FERNÁNDEZ, O. 2005a. Informe do control arqueolóxico na rúa de San Carlos, na Cidade de A Coruña. Informe valorativo inédito.

PRADO FERNÁNDEZ, O. 2005b. Informe valorativo e memoria técnida do control arqueolóxico na rúa Santa Catalina, 12. Informe-memoria inédito.

PRADO FERNÁNDEZ, O. 2006a. Informe valorativo e Memoria técnica das sondaxes arqueolóxicas nas rúas de San Carlos 3-5-7-9 e Tinajas 24. Concello da Coruña. Informe-memoria inédito.

PRADO FERNÁNDEZ, O. 2006b. Informe valorativo e memoria técnica das sondaxes arqueolóxicas na rúa Barrera, $n^{o} 32$, A Coruña. Concello da Coruña. Informe-memoria inédito.

PRADO FERNÁNDEZ, O. 2006c. Informe valorativo e memoria técnica de control arqueolóxico na rúa Galera no 26-28, na cidade da Coruña (A Coruña). Informe-memoria inédito.

PRADO FERNÁNDEZ, O. 2007. Memoria técnica de sondaxes arqueolóxicas nas rúas Real $n^{\circ} 4 e$ Galeras $n^{0}$, na cidade da Coruña. Memoria técnica inédita.

PRADO FERNÁNDEZ, O. 2008a. Informe de control arqueolóxico nas rúas de San Carlos 3-5-7-9e Tinajas 24. Concello da Coruña. Informe valorativo inédito.

PRADO FERNÁNDEZ, O. 2008b. Memoria técnica de conservación e posta en valor dos restos arqueolóxicos nun tramo da muralla medieval da Cidade Alta da Coruña (A Coruña). Memoria técnica inédita.

PRADO FERNÁNDEZ, O. 2008c. Informe valorativo e memoria técnica de control arqueolóxico na Travesía Huertas 5. Cidade da Coruña, A Coruña. Informe-memoria inédito.

RAMIL GONZÁLEZ, E. 2000. Informe-memoria de control arqueolóxico. San Andrés 17-19. A Coruña. Informe-memoria inédito.

RAMIL GONZÁLEZ, E. 2001. Praza de Azcárraga, 11 (A Coruña). Informe valorativo. Informe valorativo inédito.

RAMIL GONZÁLEZ, E. 2003. Sondaxes arqueolóxicas valorativas nos inmobles $n^{\circ} 2$ da rúa Tabernas e $n^{\circ} 6$ da rúa Santiago da cidade de A Coruña (A Coruña). Informe valorativo. Informe valorativo inédito, Consellería de Cultura e Deporte, Xunta de Galicia, Santiago de Comspotela.

RAMIL GONZÁLEZ, E. 2004a. Sondaxes arqueolóxicas valorativas nos inmobles $n^{o} 2$ da rúa Tabernas e no 6 da rúa Santiago da cidade de A Coruña (A Coruña). Memoria técnica. Memoria técnica inédita.

RAMIL GONZÁLEZ, E. 2004b. Cortaduría, 8. Praza da Cortaduría, 2 (A Coruña). Informe memoria. Informe-memoria inédito.

RAMIL GONZÁLEZ, E. 2004c. San Roque, 28 (A Coruña). Control arqueolóxico. Informe-memoria. Informe-memoria inédito.

RAMIL GONZÁLEZ, E. 2006. R/ Tinajas, 3 (A Coruña). Informe-memoria. Informe-memoria inédito. RAMIL GONZÁLEZ, E. 2008. Informe valorativo/Memoria técnica: R/ Real 63-Avda. Marina 28 (A Coruña). Informe-memoria inédito. 
RAMIL GONZÁLEZ, E. 2009a. $R$ / Tabernas $N^{o} 18$ (A Coruña). Informe valorativo. Informe valorativo inédito.

RAMIL GONZÁLEZ, E. 2009b. R/ Tabernas $N^{o} 18$ (A Coruña). Memoria técnica. Memoria técnica inédita.

RAMIL GONZÁLEZ, E. 2013. "Sondaxes arqueolóxicas na Rúa Tabernas 18, da cidade da Coruña". En M. P. Fernández Campos (coord.). Actuacións arqueolóxicas (ano 2009). Santiago de Compostela, pp. 112-113.

RAMIL REGO, E. 2001. Sondaxes valorativas previas ás obras de rehabilitación do Cuartel de Macanaz. Futura Sede da Fundación Luís Seoane. Informe valorativo inédito.

RAMIL REGO, E. 2002. Ampliación de sondaxes nas obras de Rehabilitación do Cuartel de Macanaz. Futura sede da Fundación Luís Seoane. Informe valorativo inédito.

RAMIL REGO, E. 2003. Memoria técnica: Sondaxe valorativo da construción dun foxo de ascensor na rúa do Repeso, $n^{o} 5$. Memoria técnica inédita.

RODRÍGUEZ AÑÓN, M.E. 2002. Memoria técnica. Sondaxes arqueolóxicas valorativas previas en Rúa Florida, 26. Memoria técnica inédita.

RODRÍGUEZ CASTRO, A.M. 2010. Memoria técnica de sondeos arqueológicos valorativos. Rehabilitación del edificio situado en el número 14 de la Calle Amargura. A Corruña. Memoria técnica inédita.

RODRÍGUEZ CASTRO, A.M. 2011a. Memoria técnica de sondeos arqueológicos valorativos: Rehabilitación del edificio situado en la calle Franja $N^{o} 24$ (A Coruña). Memoria técnica inédita.

RODRÍGUEZ CASTRO, A.M. 2011b. Actuaciones de instalación de redes de telecomunicaciones Orange en zona PEPRI del concello de A Coruña, 2017. Actuación en calle Fuente Seoane No 12-14. Informe valorativo de control y seguimiento arqueológico. Informe valorativo inédito.

RODRÍGUEZ CASTRO, A.M. 2014a. Reconstrucción y ampliación de edificio en la calle Bailén $N^{o} 1$ ( $A$ Coruña). Informe valorativo de sondeos arqueológicos. Informe valorativo inédito.

RODRÍGUEZ CASTRO, A.M. 2014b. Informe valorativo de sondeo arqueológico valorativo en C/ Damas $N^{o}$ 18, A Coruña. Informe valorativo inédito.

RODRÍGUEZ CASTRO, A.M. 2017a. Informe valorativo del control y seguimiento arqueológico y para las actuaciones de instalación de redes de telecomunicaciones de Orange en la Zona Pepri del Concello de A Coruña, 2017. Actuación en Calle Sacerdote Manuel Espiña. Informe valorativo de control y seguimiento arqueológico. Informe valorativo inédito.

RODRÍGUEZ CASTRO, A.M. 2017b. Actuaciones de instalación de redes de telecomunicaciones Orange en zona PEPRI del concello de A Coruña; 2017. Actuación en Calle San José $n^{o} 5$. Informe valorativo de control y seguimiento arqueolóxico. Informe valorativo inédito.

RODRÍGUEZ CASTRO, A.M. 2017c. Actuaciones de instalación de redes de telecomunicaciones Orange en Zona Pepri del Concello de A Coruña; 2017. Actuación en Calle Veramar $N^{o} 11$. Informe valorativo inédito.

RODRÍGUEZ CASTRO, A.M. 2017d. Actuaciones de instalación de redes de telecomunicaciones Orange en Zona Pepri del Concello de A Coruña; 2017. Actuación en Calle Veramar $N^{o}$ 23. Informe valorativo inédito.

RODRÍGUEZ COLMENERO, A. 2005. "Las nuevas "stationes Lucencis et Brigantina” en el Finisterre ibérico del Imperio Romano”. Palaeohispánica, 5, 873-892.

RODRÍGUEZ RODRÍGUEZ, O. 2000. Proyecto de instalación de cervecería en C/ Barrera 23-25. A Coruña (A Coruña). Informe-memoria inédito.

RUPIDEIRA GIRALDO, A. 2000. Sondeos arqueológicos: Memoria técnica. Riego de Agua, 4 (A Coruña). Memoria técnica inédita.

RUPIDEIRA GIRALDO, A. 2001. Excavación arqueológica Riego de Agua, 4. Memoria técnica inédita.

SAN CLAUDIO SANTA CRUZ, M. 2003 "El puerto de "Brigantium" (A Coruña) y la navegación romana en el Atlántico Norte”. En C. Fernández Ochoa (coord.), Gijón, puerto romano: navegación y comercio en el Cantábrico durante la antigüedad. Gijón, pp. 121-133. 
SÁNCHEZ PARDO, J.C. 2008. Territorio y poblamiento en Galicia entre la Antigüedad y la Plena Edad Media. Tese doutoral publicada pola Universidade de Santiago de Compostela.

SERRULLA RECH, F. 2004. "Informe antropológico restos óseos Rúa Real 34". A Coruña. Informe antropolóxico anexo a: TOMÁS BOTELLA, V. 2004. Real, 34 (A Coruña). Informe. Informe inédito.

SINDE VÁZQUEZ, A. 2009. $R$ / San Agustín $N^{o} 31$ (A Coruña). Memoria técnica intervencións arqueolóxicas. Memoria técnica inédita.

SOTO ARIAS, P. 1998. Sondaxes arqueolóxicas nos solares $n^{\circ} 9$ e $n^{o} 11$ da rúa Santa María da cidade de A Coruña. Informe valorativo inédito.

SOTO ARIAS, P. 2002. Informe valorativo: sondeos arqueológicos Calle Príncipe 9/11. Cidade Vella - A Coruña. Informe valorativo inédito.

SOTO ARIAS, P. 2004. Informe de valoración. Sondaxes arqueolóxicas na rúa Riego de Agua 3-5. A Coruña. Informe valorativo inédito.

TOMÁS BOTELLA, V. 1997. Informe control arqueolóxico. Puerta de Aires $n^{\circ}$ 2. Informe valorativo inédito.

TOMÁS BOTELLA, V. 1999. Riego de Agua 31: Sondeos arqueológicos. Informe valorativo. Informe valorativo inédito.

TOMÁS BOTELLA, V. 2000a. Memoria técnica: control arqueolóxico. Barreira, 7 (A Coruña). Memoria técnica inédita.

TOMÁS BOTELLA, V. 200ob. Sondaxes arqueolóxicas: Informe valorativo. Praza de Azcárraga, 11 (A Coruña). Informe valorativo inédito.

TOMÁS BOTELLA, V. 200oc. Rúa Real, 17 (A Coruña). Sondaxes arqueolóxicas. Informe valorativo. Informe valorativo inédito.

TOMÁS BOTELLA, V. 200od. Sondaxes arqueolóxicas: Rúa Real no 8 (A Coruña). Informe valorativo. Informe valorativo inédito.

TOMÁS BOTELLA, V. 200oe. Real, 8 (Cine París) (A Coruña). Informe valorativo. Informe valorativo inédito.

TOMÁS BOTELLA, V. 200of. Sondaxes arqueolóxicas. Informe valorativo. Real, 47 (A Coruña). Informe valorativo inédito.

TOMÁS BOTELLA, V. 200og. Sondaxes arqueolóxicas valorativas e Escavación arqueolóxica: Franxa, 54 (A Coruña). Informe valorativo inédito.

TOMÁS BOTELLA, V. 200oh. Informe valorativo: Galera, 45 ( A Coruña). Informe valorativo inédito. TOMÁS BOTELLA, V. 200oi. Memoria técnica: Galera, 45 (A Coruña). Memoria técnica inédita.

TOMÁS BOTELLA, V. 200ol. San Andrés, 9+11 (A Coruña). Informe valorativo. Informe valorativo inédito.

TOMÁS BOTELLA, V. 2000m. Ampliación de sondaxes arqueolóxicas. San Andrés, 9+11 (A Coruña). Informe valorativo. Informe valorativo inédito.

TOMÁS BOTELLA, V. 200on. Rúa Mercado, 6, 8 e 10 (A Coruña). Informe valorativo inédito.

TOMÁS BOTELLA, V. 2001a. Tabernas, 10 (A Coruña). Informe valorativo. Informe valorativo inédito.

TOMÁS BOTELLA, V. 2001b. Real 34, A Coruña. Sondaxes arqueolóxicas. Informe valorativo. Informe valorativo inédito.

TOMÁS BOTELLA, V. 2001c. Informe valorativo Rúa da Franxa, 47 (A Coruña). Informe valorativo inédito.

TOMÁS BOTELLA, V. 2001d. Franxa 54 (A Coruña). Memoria técnica. Memoria técnica inédita.

TOMÁS BOTELLA, V. 2001e. Control arqueolóxico no solar no 6-1o da rúa Mercado (A Coruña). Informe. Informe inédito.

TOMÁS BOTELLA, V. 2002a. Tabernas, 10 (A Coruña). Informe valorativo. Informe valorativo inédito.

TOMÁS BOTELLA, V. 2002b. Tabernas, 22 (A Coruña). Informe valorativo. Informe valorativo inédito.

TOMÁS BOTELLA, V. 2002c. Praza de María Pita, 18 (A Coruña). Informe valorativo/Memoria técnica. Informe-memoria inédito. 
TOMÁS BOTELLA, V. 2002d. Mercado, 14 (A Coruña). Informe valorativo/Memoria técnica. Informe-memoria inédito.

TOMÁS BOTELLA, V. 2002e. Varela Silvari, 29+31 (A Coruña). Control arqueolóxico. Informe valorativo/Memoria técnica. Informe-memoria inédito.

TOMÁS BOTELLA, V. 2003a. Tabernas $n^{\circ} 10$ (A Coruña). Actuación: sondaxees arqueolóxicas. Informe valorativo. Informe valorativo inédito.

TOMÁS BOTELLA, V. 2003b. Tabernas $n^{\circ} 12$ (A Coruña). Actuación: escavación arqueolóxica. Informe valorativo. Informe valorativo inédito.

TOMÁS BOTELLA, V. 2003c. Real 34, A Coruña. Informe valorativo. Informe valorativo inédito.

TOMÁS BOTELLA, V. 2003d. San André Na 52. A Coruña. Informe valorativo/Memoria técnica. Informe-memoria inédito.

TOMÁS BOTELLA, V. 2003e. San Roque $N^{o} 30$ (A Coruña). Informe valorativo/Memoria técnica. Informe-memoria inédito.

TOMÁS BOTELLA, V. 2004a. Sondaxes arqueolóxicas: Informe/Memoria R/Capitán Troncoso, 9 (A Coruña). Informe-memoria inédito.

TOMÁS BOTELLA, V. 2004b. Real, 34 (A Coruña). Informe. Informe valorativo inédito.

TOMÁS BOTELLA, V. 2004c. C/ Real $n^{\circ} 67$ Avda. Da Mariña $n^{o}$ 3o. Informe valorativo. Informe valorativo inédito.

TOMÁS BOTELlA, V. 2004d. Praza de María Pita, 22 (A Coruña). Control arqueolóxico. Informe valorativo inédito.

TOMÁS BOTELLA, V. 2005a. R/ Tabernas, 21 (A Coruña). Informe valorativo. Informe valorativo inédito.

TOMÁS BOTELlA, V. 2005b. R/ Tinajas, 4 (A Coruña). Informe valorativo. Informe valorativo inédito.

TOMÁS BOTELlA, V. 2005c. Real, 67/Avda. Da Mariña, 30 (A Coruña). Informe valorativo inédito.

TOMÁS BOTELlA, V. 2005d. Polígono 5. Plaza de María Pita-San Agustín-Florida (A Coruña). Informe valorativo. Informe valorativo inédito.

TOMÁS BOTELLA, V. 2005e. San André, 148-15o (A Coruña). Informe valorativo/Memoria técnica. Informe-memoria inédito.

TOMÁS BOTELLA, V. 2005f. R/ Sinagoga, 19-21 (A Coruña). Informe valorativo. Informe valorativo inédito.

TOMÁS BOTELLA, V. 2006a. R/ Amargura, 17 (A Coruña). Informe valorativo. Informe valorativo inédito.

TOMÁS BOTELLA, V. 2006b. R/ Franxa, 33 (A Coruña). Informe valorativo. Informe valorativo inédito.

TOMÁS BOTELLA, V. 2006c. R/ Sinagoga, 19-21 (A Coruña). Informe puntual control de obra. Informe valorativo inédito.

TOMÁS BOTELLA, V. 2006d. R/ Sánchez Bregua, 3. Informe valorativo. Informe valorativo inédito.

TOMÁS BOTELLA, V. 2006e. R/ San Roque, 4 (A Coruña). Informe/memoria técnica. Informe-memoria inédito.

TOMÁS BOTELLA, V. 2007a. R/ Príncipe, 17 (A Coruña). Informe valorativo. Informe valorativo inédito.

TOMÁS BOTELLA, V. 2007b. Parrote 14 (A Coruña). Sondaxes arqueolóxicas. Informe valorativo inédito.

TOMÁS BOTELLA, V. 2007c. Praza de Azcárraga, 3 (A Coruña). Memoria técnica. Informe-memoria inédito.

TOMÁS BOTELLA, V. 2007d. Informe puntual control de obra: R/ Amargura, 17 (A Coruña). Informe valorativo inédito.

TOMÁS BOTELLA, V. 2007e. R/ Barreira 8-10 / San Nicolás 5 (A Coruña). Sondaxes arqueolóxicas. Informe valorativo inédito.

TOMÁS BOTELLA, V. 2007f. Informe valorativo/Memoria técnica: R/ Capitán Troncoso, 4 (A Coruña). Informe-memoria inédito. 
TOMÁS BOTELLA, V. 2007g. R/ Cortaduría, 12 (A Coruña). Informe puntual control arqueolóxico. Informe inédito.

TOMÁS BOTELLA, V. 2007h. Real, 24 (A Coruña). Informe valorativo. Informe valorativo inédito.

TOMÁS BOTELLA, V. 2007i. Informe valorativo: R/ Galera, 51-53; R/ Xeneral Mola, 12 (A Coruña). Informe valorativo inédito.

TOMÁS BOTELLA, V. 2007l. R/ Sánchez Bregua, 2 (A Coruña). Informe valorativo. Informe valorativo inédito.

TOMÁS BOTELLA, V. 2008a. R/ Tabernas $N^{o} 20$ (A Coruña). Informe valorativo. Informe valorativo inédito.

TOMÁS BOTELLA, V. 2008b. R/ Santiago N13-15 (A Coruña). Informe valorativo/Memoria técnica. Informe-memoria inédito.

TOMÁS BOTELLA, V. 2008c. R/ Sánchez Bregua, 3. Escavación en área. Informe valorativo inédito.

TOMÁS BOTELLA, V. 2009. Praza de España $n^{\circ}$ 16, 17, 18, 19 e 20. R/ Varela Silvari no 40 e $44(A$ Coruña). Informe valorativo/Memoria técnica. Informe-memoria inédito.

TOMÁs BOTELlA, V. 2010. Parrote 14 (A Coruña). Control arqueolóxico. Informe incidencias. Informe valorativo inédito.

TOMÁS BOTELLA, V. 2012. Real, 55. A Coruña. Informe valorativo. Informe valorativo inédito.

TOMÁS BOTELLA, V. 2014. Praza de Millán Astray No 6 (A Coruña). Informe valorativo inédito.

TOMÁS BOTELLA, V. 2015a. Rego de Auga $n^{o} 7$ (A Coruña). Sondaxes arqueolóxicas. Memoria técnica. Memoria técnica inédita.

TOMÁs BOTEllA, V. 2015b. Riego de Agua 23 (A Coruña). Memoria técnica. Memoria técnica inédita.

TOMÁS BOTELlA, V. 2016. R/ Damas, 13 (A Coruña). Memoria técnica. Memoria técnica inédita.

VÁZQUEZ COLLAZO, S. 1998a. Escavación arqueolóxica en área no solar (fincas $n^{\circ} 24-28$ ) da futura sé da fundación Caixa Galicia no Cantón Grande (A Coruña). Informe de valoración. Informe valorativo inédito.

VÁZQUEZ COLLAZO, S. 1998b. Escavación arqueolóxica en área nas fincas 21-24 do Cantón Grande ( $A$ Coruña). Informe de valoración. Informe valorativo inédito.

VÁZQUEZ COLLAZO, S. 1998c. Control arqueolóxico da desmontaxe das estruturas romanas rexistradas no solar (fincas $n^{o} 21$ a 24) da futura sé da Fundación Caixa Galicia no Catnón Grande (A Coruña). Informe de valoración. Informe valorativo inédito.

VÁZQUEZ COLLAZO, S. 1999a. Escavación arqueolóxica na beirarrúa do Cantón Grande (A Coruña). Informe de valoración. Informe valorativo inédito.

VÁZQUEZ COLLAZO, S. 1999b. Escavación arqueolóxica na Beirarrúa do Cantón Grande - A Coru$\tilde{n} a\left(2^{a}\right.$ Fase $\left.-A\right)$. Informe de valoración. Informe valorativo inédito.

VÁZQUEZ COLLAZO, S. 1999c. Escavación arqueolóxica na beirarrúa do Cantón Grande - A Coruña ( ${ }^{a}$ Fase - A; fronte Cine Avenida). Informe valorativo inédito.

VÁZQUEZ COLLAZO, S. 1999d. Escavación arqueolóxica na Beirarrúa do Cantón Grande - A Coruña (2 ${ }^{a}$ Fase - B). Informe de valoración. Informe valorativo inédito.

VÁZQUEZ COLLAZO, S. 1999e. Sondaxes arqueolóxicas valorativas na finca no 23 da Rúa da Estrela (A Coruña). Informe de valoración. Informe valorativo inédito.

VÁZQUEZ COLLAZO, S. 1999f. Sondaxes arqueolóxicas valorativas no no 29 da rúa Florida (A Coruña). Memoria técnica. Memoria técnica inédita.

VÁZQUEZ COLLAZO, S. 2002a. Sondaxes arqueolóxicas valorativas realizadas na Rúa Galera, nº 9 ( $A$ Coruña). Memoria técnica inédita.

VÁZQUEZ COLLAZO, S. 2002b. Control de remoción de terras final realizado na Rúa Galera, nº 9 (A Coruña). Informe de valoración. Informe valorativo inédito.

VÁZQUEZ COLLAZO, S. 2003. Sondaxes arqueolóxicas valorativas na Rúa Franxa No 23 - Esquina Rúa Trompeta (A Coruña). Informe de valoración. Informe valorativo inédito.

VÁZQUEZ COLLAZO, S. 2004. Control de remoción de terras final realizado na Rúa Franxa, $N^{\circ} 23$ (A Coruña). Informe de valoración. Informe valorativo inédito. 
VÁZQUEZ COLLAZO, S. 2015. Control e seguimento arqueolóxico das obras de urbanización de "La Marina" (A Coruña). Memoria técnica sobre a intervención na ventá arqueolóxica de Porta Real. Memoria técnica inédita.

VÁZQUEZ GÓMEZ, X.L. 1988. Memoria Igresia de Santiago, A Coruña. Campaña de 1988. Memoria técnica inédita.

VÁZQUEZ GÓMEZ, X.L. 1991. La Coruña en época romana. En J. M. Bello Diéguez, e A. Vigo Trasancos. Ciudad y Torre. Roma y la ilustración en la Coruña. A Coruña, pp- 35-39.

VÁZQUEZ GÓMEZ, X..L. 1993/1994. “Tres marcas de alfareiro en Terra Sigillata atopadas en A Coruña”. Brigantium, 8, 293-299.

VÁZQUEZ GÓMEZ, X.L. 1994. Informe valorativo da sondaxe realizada no Cantón Grande. A Coru$\tilde{n} a$. Informe valorativo inédito.

VÁZQUEZ GÓMEZ, X.L. 1995a. "Escavación arqueolóxica de urxencia na Praza de San Agustín (A Coruña). En VV.AA. (coord.). Arqueoloxía Informes, 3. Santiago de Compostela, pp. 131-134.

VÁZQUEZ GÓMEZ, X.L. 1995b. "Escavación arqueolóxica de urxencia na Praza Xeneral Cánovas Lacruz (A Coruña). En VV.AA. (coord.). Arqueoloxía Informes, 3. Santiago de Compostela, pp. 135-138.

VÁZQUEZ GÓMEZ, X.L. 1996. “Excavación en la Calle de la Franja 9-11”. Gallaecia, 14-15, 411-461.

VÁZQUEZ GÓMEZ, X.L. 1999. Informe-memoria das sondaxes arqueolóxicas valorativas na beirarrúa do Cantón Grande. A Coruña. Informe-memoria inédito.

VÁZQUEZ GÓMEZ X.L. 2008. "Brigantium á luz da arqueoloxía”. Férvedes, 5, pp. 353-361.

VIDAL CAEIRO, L. 2006. Escavación arqueolóxica na rúa Santo Domingo, $n^{\circ} 6$ ( A Coruña). Informe valorativo. Informe valorativo inédito.

VIDAL CAEIRO, L. 2009. Escavación arqueolóxica na rúa Santo Domingo, 6 (A Coruña). Memoria técnica inédita.

VILCHES MARTÍN, C. 2011. Reconstrucción, ampliación y agrupación funcional para tres viviendas y comerciales de los edificios $n^{\circ} 10$ y 12 de la Calle Bailén. A Coruña. Control y seguimiento arqueológico. Informe-memoria inédito.

VILCHES MARTÍN, C. 2013. Informe valorativo de sondeo arqueológico en C/ Amargura $N^{o}$ 6, A Coruña. Informe valorativo inédito.

VILCHES MARTÍN, C. 2017. Apertura de zanja para reparación de acometida de alcantarillado en la Calle San Juan $n^{o} 11$ (A Coruña). Informe-memoria de control y seguimiento arqueológico. Informe-memoria inédito. 